\title{
10. HIGH-RESOLUTION CARBONATE AND ORGANIC-CARBON STRATIGRAPHIES FOR THE LATE NEOGENE AND QUATERNARY FROM THE WESTERN CARIBBEAN AND EASTERN EQUATORIAL PACIFIC ${ }^{1}$
}

\author{
James V. Gardner, U.S. Geological Survey, Menlo Park, California
}

\begin{abstract}
Concentrations of calcium carbonate and organic carbon were determined in closely spaced samples from two nearly continuous sections of the late Neogene and Quaternary, one from Site 502 in the western Caribbean and the other from Site 503 in the eastern equatorial Pacific. Each section records the past $7.5 \mathrm{~m} . \mathrm{y}$. with a sampling interval of approximately every $5 \mathrm{k}$.y. Both sections show cyclic carbonate concentrations with three classes of dominant periodicities. The longest-period carbonate cycles have periods of 500 to 600 k.y. and appear to be broad-scale oceanic responses. These cycles appear throughout the entire Pacific record but only occur in the 4.0 to $7.5 \mathrm{~m} . \mathrm{y}$. interval in the Caribbean record. This difference is probably related to the more active tectonic setting of Site 502 and the oceanic character of Site 503. Intermediate-scale carbonate cycles, S-cycles, occur throughout both records, but the only interval that can be correlated between the two is the 0 to $1.4 \mathrm{~m}$.y. interval. These cycles can also be correlated with records of changes in other Pleistocene sections. The range of periodicities of the S-cycles suggests they are responses to global climatic changes that are in phase with the eccentricity of the Earth's orbit.

The smaller-scale carbonate cycles, C-cycles, also occur throughout both records but are difficult to correlate because of the different settings of the two sites. C-cycles are apparently out-of-phase between the two sites from 7.5 to 4.0 Ma, but then, inexplicably, they become much more similar in trend from 4.0 Ma to present. C-cycles have periodicities that fall in the range typical of these of the obliquity of the Earth's orbit, again suggesting a control by global climatic changes.

Organic-carbon concentrations show no correlation with carbonate in the western Caribbean section but they show a strong negative correlation with carbonate in the eastern equatorial Pacific record. The relationship in the Pacific section is opposite to that found by others, and the relationships at both sites are opposite to what one would intuitively expect.
\end{abstract}

\section{INTRODUCTION}

Carbonate stratigraphy is often used in studies of Quaternary marine sections to delineate global climatic zonations, using the correlation between relative percentages of carbonate and periods of global glacial and interglacial conditions. There are only a few studies of Neogene carbonate stratigraphy, and they have used either: (1) a series of widely separated piston cores combined into a composite section, (2) sections with very slow accumulation rates, or (3) highly disturbed sections obtained by rotary drilling from Deep Sea Drilling Project (DSDP) sites. Composite piston-core methods have the problems of not being a continuous sequence from one location and necessarily slow accumulation rates. The Neogene and Quaternary sections recovered by DSDP rotary drilling are generally disturbed by the drilling technique so that any high-resolution record is smeared or lost. Leg 68 of DSDP, on the other hand, recovered long, nearly continuous, virtually undisturbed, fast-accumulation rate sections from the Caribbean and from the eastern equatorial Pacific using the hydraulic piston corer (HPC). The section recovered at each site spans at least the past $7 \mathrm{~m}$.y. and for the first time gives us an opportunity to investigate in continuous sections the detailed carbonate stratigraphy for the late Neogene and Quaternary from the Pacific and Caribbean.

\footnotetext{
${ }^{1}$ Prell, W. L., Gardner, J. V., et al., Init. Repts. DSDP, 68: Washington (U.S. Govt. Printing Office).
}

Quantitative analyses of the carbonate history preserved in deep-sea sediment was pioneered by Arrhenius (1952) and was followed by work of Olausson (1965, 1967), Wiseman (1965), and then numerous studies in the 1970s. All of these utilized samples from gravity or piston cores that recovered, at the maximum, about 20 meters of core. The longest continuous record recovered in these cores is a little over 6 m.y. of the late Neogene and Quaternary (Hays et al., 1969) but high-resolution detail of the record is lost because of slow accumulation rates. At the other extreme are fast accumulation-rate records (see, for example, Thompson and Saito, 1974; Prell, 1978), but the drawback to these cores is that the detailed record is only for the past $1 \mathrm{~m}$.y. or less. Leg 68 returned to areas known to have had fast accumulation rates of calcareous sediment and thought to be continuous for the late Neogene and Quaternary with one of the objectives being to extend the detailed carbonate stratigraphy.

\section{General Description of the Recovered Sediment}

The section at Site 502 in the Colombian Basin (Fig. 1) was recovered in four holes cored to a total sub-bottom depth of 228.7 meters. Two holes were cored at Site 503 on the northern flank of Galapagos Ridge (Fig. 2) to a total depth of 235 meters sub-bottom. The basal sediment from Site 502 is within the late Miocene Didymocyrtis antipenultimus zone (radiolarians), which is older than 7.5 m.y. (see site chapter, Site 502, this volume). The oldest sediment recovered at Site 503 is also late 


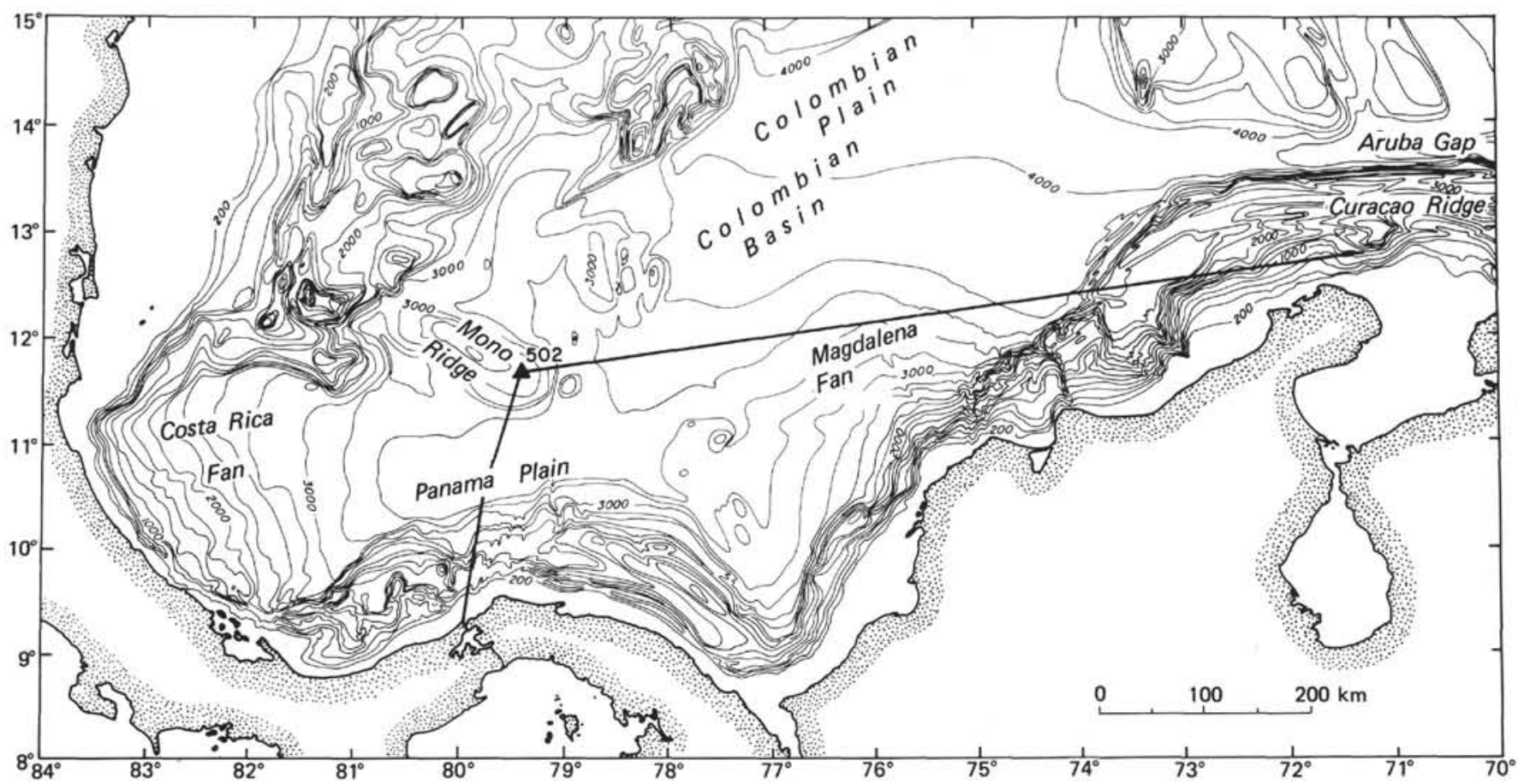

Figure 1. Location of Site 502 and trackline of Glomar Challenger Leg 68 in the Caribbean. (Depths in m.) (After Holcombe, 1975.)

Miocene, based on all biostratigraphic groups (see site chapter, Site 503, this volume). Sediment from Site 502 is a hemipelagic facies with variable amounts of calcareous-biogenic, terrigenous, and volcanogenic components. This is in contrast to the pelagic facies recovered from Site 503, which has variable abundances of foraminifers, nannofossils, diatoms, and radiolarians together with clay minerals and volcanic ash. This difference in facies between the two sites indicates the different factors that controlled sedimentation at each site. Site 502 has been influenced by terrigenous debris delivered to the Caribbean by the Rio Magdalena and the continental margin of Central America and northern South America. The flux of sediment to Site 502 has been modified by the tectonic uplift of the horst upon which the site is located (Fig. 3). At Site 503, however, siliceous- and calcareous-biogenic components accumulated with only minor inputs of terrigenous (principally volcanic ash) material. The only tectonic process active at Site 503 has been the slow subsidence of the plate as it proceeded away from the Galapagos Ridge.

\section{METHODS}

Carbonate data were gathered by two different methods. Aboard ship, the Carbonate Bomb method of Müller and Gastner (1971) was used. The majority of samples were analyzed ashore using modified $\mathrm{LECO}^{2}$ carbon analyzers. Splits of material analyzed by bomb were also run on the modified LECO; the differences are less than $\pm 2 \%$. Therefore, the data sets were merged with little or no loss of accuracy.

Samples used for the LECO analyses were oven dried, split, weighed, and then one split was combusted at $1600^{\circ} \mathrm{C}$ for total carbon. At least two analyses were run and averaged for each total carbon determination. A second split was dissolved in $6 \mathrm{~N} \mathrm{HCl}$, and the

\footnotetext{
${ }^{2}$ The use of trade names is for descriptive purposes only and does not constitute an endorsement by the U.S. Geological Survey.
}

percentage of carbon in the liberated $\mathrm{CO}_{2}$ (inorganic carbon) was measured by changes in thermal conductivity. Calcium carbonate, hereafter called simply carbonate, and organic carbon are calculated using the following relationships:

$$
\begin{aligned}
& \mathrm{CaCO}_{3}=\frac{\mathrm{C}_{\mathrm{I}}}{0.12} \\
& \mathrm{C}_{\mathrm{o}}=\mathrm{C}_{\mathrm{T}}-\mathrm{C}_{\mathrm{l}},
\end{aligned}
$$

where $C_{I}$ is percent (by weight) inorganic carbon, $C_{0}$ is percent organic carbon, and $\mathrm{C}_{\mathrm{T}}$ is percent total carbon. The constant 0.12 is the mole fraction of carbon in $\mathrm{CaCO}_{3}$. The accuracy of LECO is $\pm 0.1 \%$ for $\mathrm{C}_{\mathrm{T}}$ and $\pm 1 \%$ for $\mathrm{C}_{\mathrm{I}}$. The precision on replicate runs for carbonate was $\pm 1 \%$.

Carbonate data were first plotted versus depth for each hole (Fig. 4). Data from different holes at each site were compared (see Appendix A, microfiche, back pocket) and gaps in recovery from one hole were filled in by data from another hole at the appropriate interval. The correlation of two adjacent holes was made using magnetostratigraphic boundaries as tie points, but minor offsets in depth were required at times to make a convincing match. Once a satisfactory composite section was constructed (Appendix B, this chapter), a time section was made using only the ages of the included magnetostratigraphic boundaries as time datums. Thirteen paleomagnetic datums were used for the composite section for Site 502 and seven datums were used for the composite section for Site 503 (Table 1). The depths of these datums are known to within $30 \mathrm{~cm}$ (approximately $10 \mathrm{k} . \mathrm{y}$.) with only two exceptions $(56 \mathrm{~cm}$ and $60 \mathrm{~cm}$ ). Ages were assigned to these paleomagnetic datums using the revised paleomagnetic time scale of LaBrecque et al. (1977). The depth plots were converted into age plots by calculating an average accumulation rate between two adjacent known paleomagnetic datums and then, by linear interpolation, assigning an age to each depth point. The section below the last known paleomagnetic datum was converted to age by extrapolating the last calculated average accumulation rate to the interval. Plots of organic carbon were constructed in a similar manner using the composite section developed for the carbonate stratigraphy.

One of the difficulties posed by such long, high-resolution records is the choice of nomenclature for identifying individual cycles on the record. I have chosen not to use the nomenclature of oxygen-isotope stages because my data are carbonate percentages and not isotope 


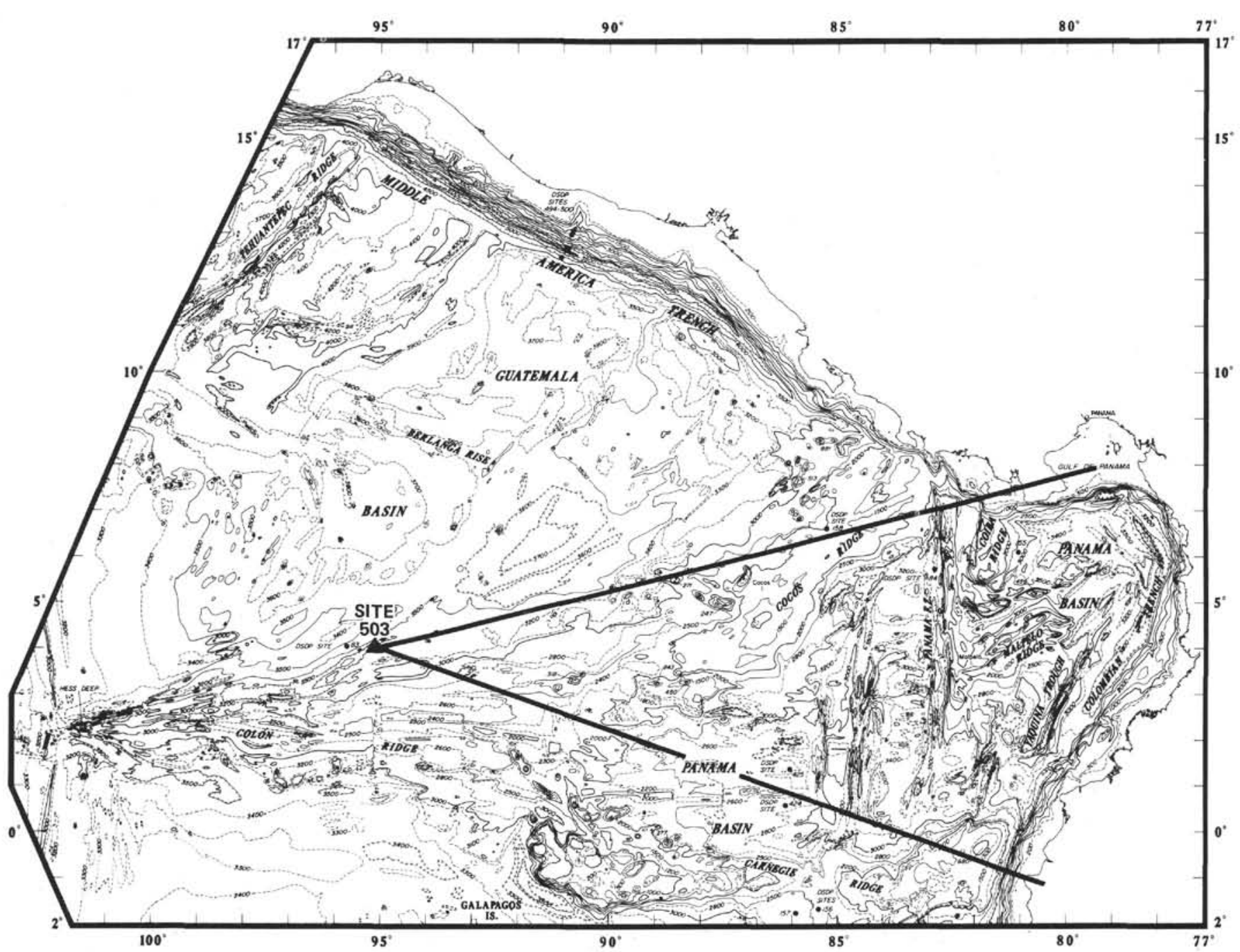

Figure 2. Location of Site 503. (Depth in m.) (After Chase et al., 1970; Mammerickx et al., 1974.)

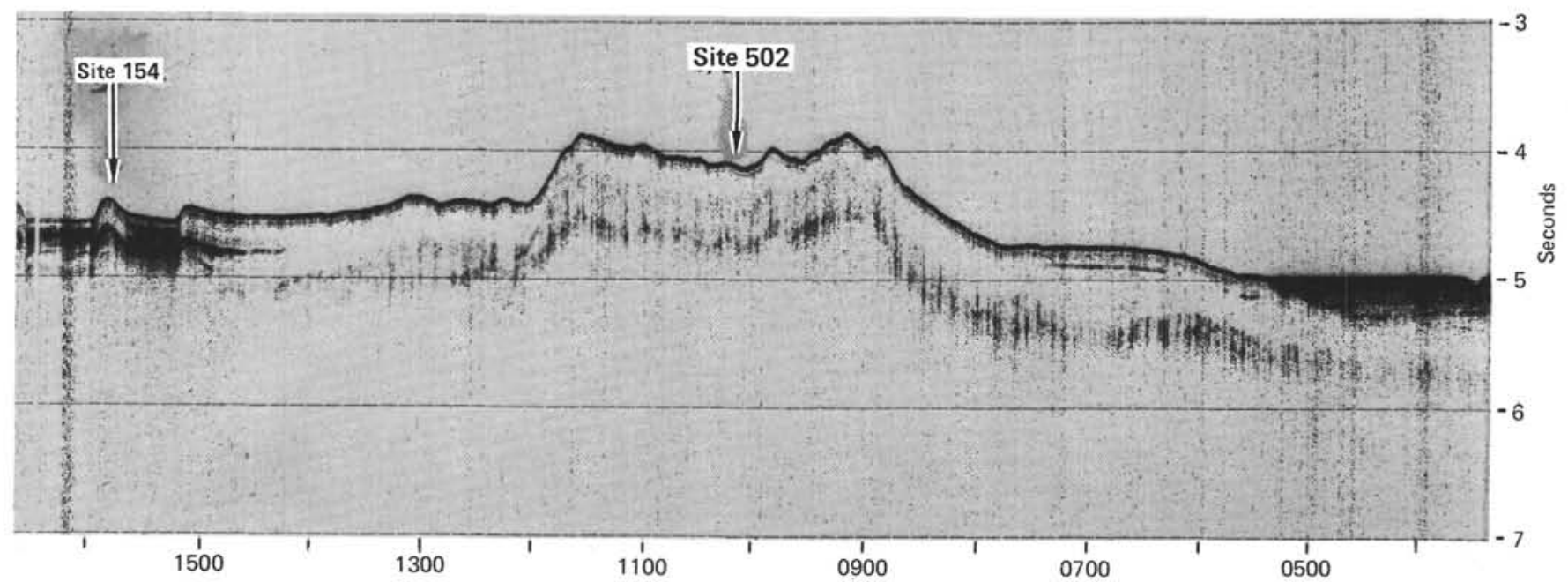

Figure 3. Seismic-reflection profile across the approximate location of Site 502. (After Edgar et al., 1973.) 


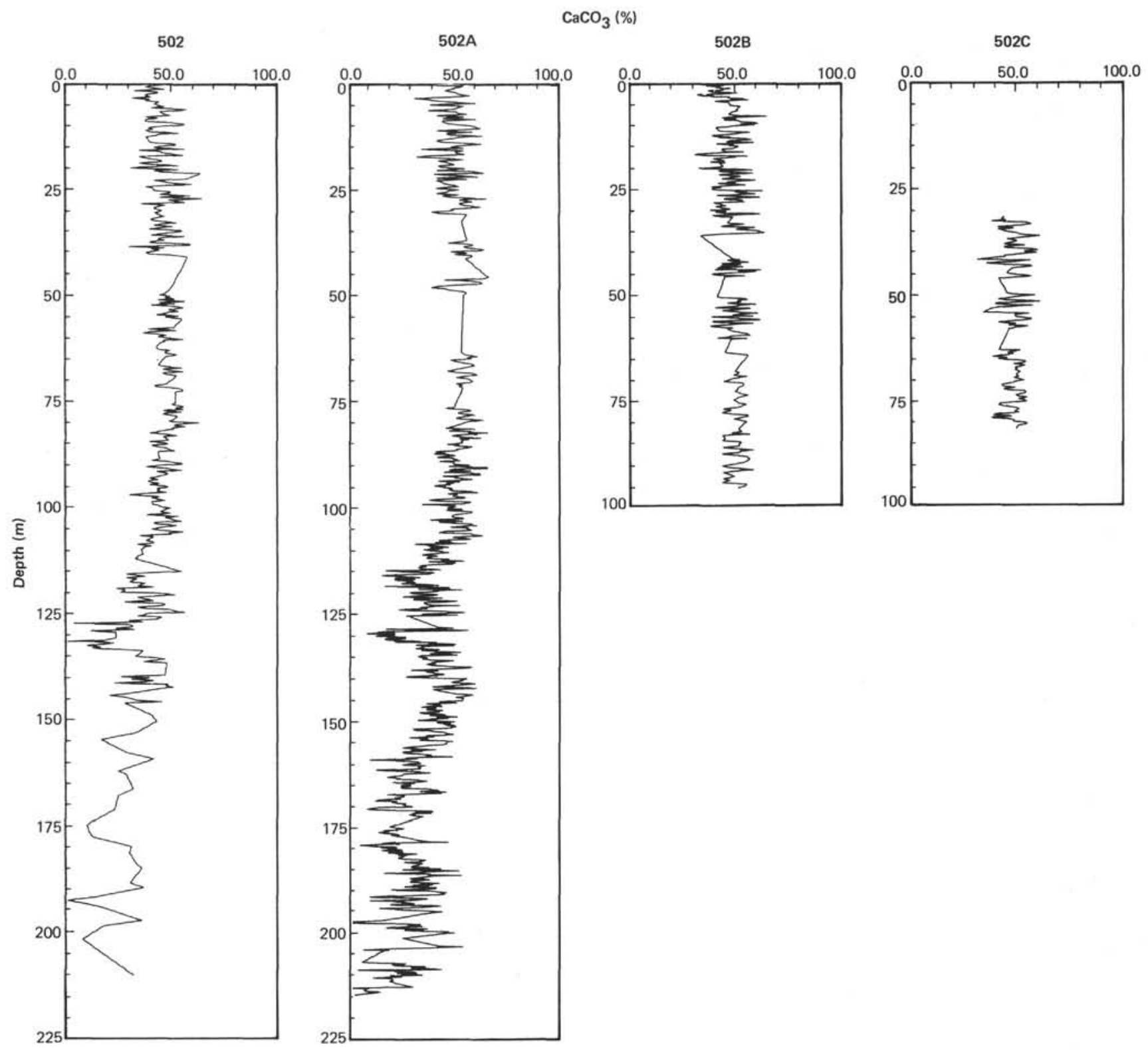

Figure 4. Carbonate versus depth plots for each hole at Sites 502 and 503. (See Appendix A for a tabulation of the data.)

composition. There are no assurances that percent carbonate and oxygen-isotope composition are in phase; in fact, Broecker (1971); Luz and Shackleton (1975); Pisias et al. (1975); Ninkovich and Shackleton (1975); and Moore et al. (1977) all show that carbonate concentration lags the oxygen-isotope response by several thousand years. So as not to confuse the literature any more than necessary, a modified version of the nomenclature of Hays et al. (1969) was adopted for numbering carbonate cycles on the composite sections. Cycles have been sequentially numbered between paleomagnetic datums using consecutive numbers followed by a code for paleomagnetic polarity zone.

\section{CARBONATE STRATIGRAPHY AT SITE 502}

\section{Description of the Carbonate Record}

The overall trend of carbonate at Site 502 (Fig. 5A, back pocket, this volume) shows a gradual increase in average carbonate content from $7.5 \mathrm{Ma}$ until about 3.8 m.y. The average carbonate content is relatively constant between $3.8 \mathrm{Ma}$ and the present. Cyclic fluctua- tions of several different periods are seen in the record. The longest wavelength cycle appears to have a period of about $500 \mathrm{k} . \mathrm{y}$. and is apparent in the interval between the late Miocene through early Pliocene. This periodicity dies out at about 3.8 Ma. However, quasi-periodic fluctuations with shorter periods occur throughout the record.

Super cycles, hereafter called S-cycles, represent sections of the carbonate record between two relatively low carbonate valleys. S-cycles were identified by first drawing a baseline connecting the extreme carbonate minima. Those carbonate minima that either touched or are within about $5 \%$ carbonate of the baseline were used as boundaries for S-cycles. Those carbonate minima that are coincident with volcanic ash layers were excluded.

S-cycles often include several smaller-wavelength and smaller-amplitude cycles termed C-cycles. These are the 


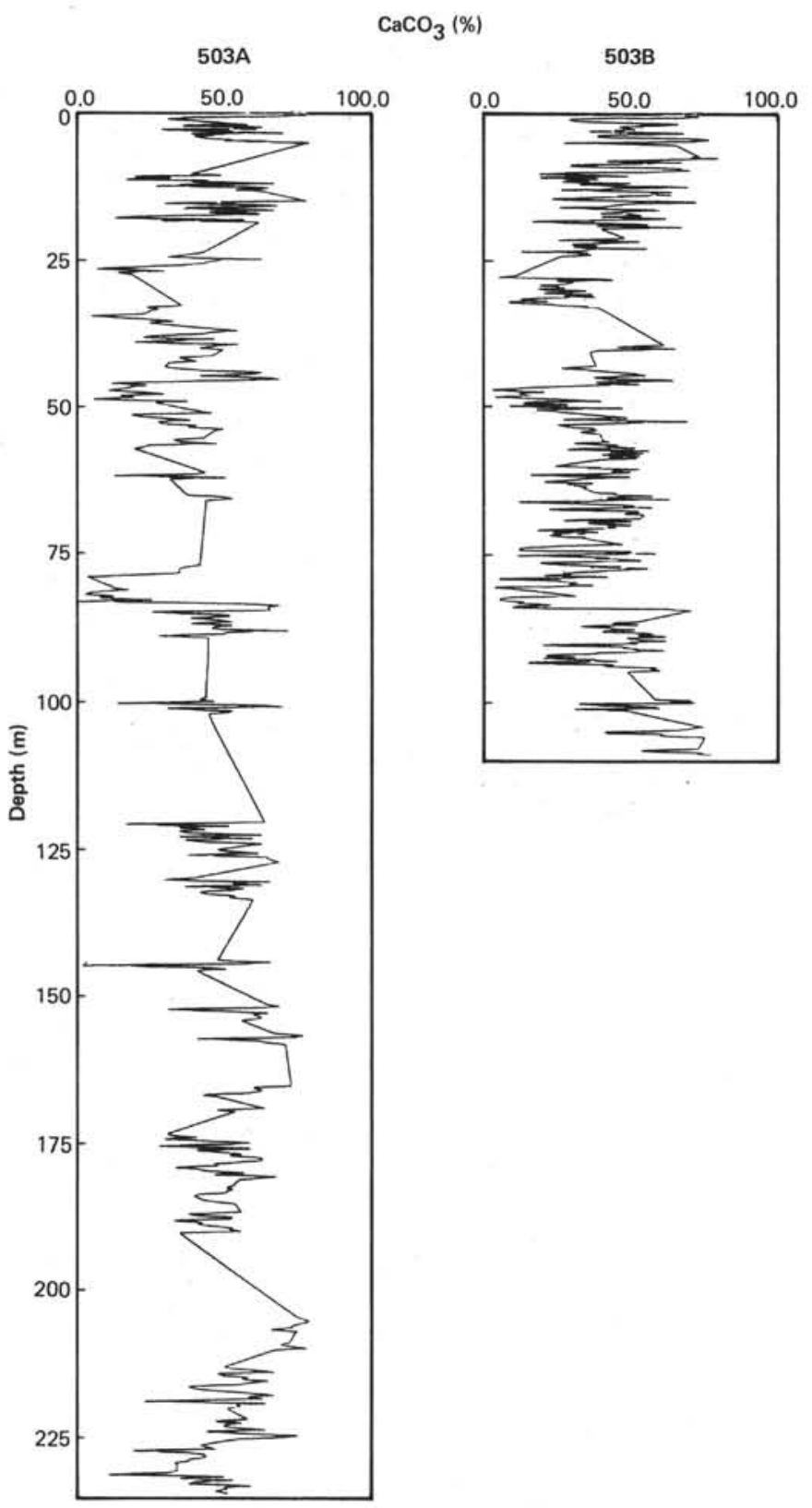

Figure 4. (Continued).

fundamental carbonate fluctuations and are defined by individual peaks of carbonate that are judged to be discrete and not a shoulder of an adjacent peak or an artifact of the analytical method. S- and C-cycles are found throughout the record but with different frequencies. The record has been subdivided into segments $0.5-\mathrm{m} . \mathrm{y}$. long, and the number and periodicity of each type of cycle is tabulated in Table 2. The overall periodicity of S-cycles has decreased since $7.5 \mathrm{Ma}$, but the decrease is not linear whereas the periodicities of $\mathrm{C}$-cycles show no clear trend with time (Fig. 6).

Average carbonate content (Table 3) increases through the upper Miocene section although the increase is superimposed on the $500 \mathrm{k}$.y. fluctuation described above. The average carbonate content for the upper Miocene section is $28 \%$ ( $\sigma= \pm 11 \%)$. S-cycles in the upper Mio-
Table 1. Paleomagnetic datums used to construct composite sections for Sites 502 and 503.

\begin{tabular}{llrr}
\hline Hole & \multicolumn{1}{c}{$\begin{array}{c}\text { Paleomagnetic } \\
\text { Datum }\end{array}$} & $\begin{array}{c}\text { Sub-bottom } \\
\text { Depth } \\
(\mathrm{m})\end{array}$ & \multicolumn{1}{c}{$\begin{array}{c}\text { Age } \\
(\mathrm{y})\end{array}$} \\
\hline 502B & Brunhes/Matuyama & 16.25 & 730,000 \\
502B & Base of Jaramillo & 21.43 & 980,000 \\
502 & Top of Olduvai & 38.07 & $1,660,000$ \\
502A & Base of Olduvai & 42.33 & $1,880,000$ \\
502B & Top of Kaena & 73.51 & $2,920,000$ \\
502B & Base of Kaena & 75.59 & $2,990,000$ \\
502 & Top of Mammoth & 79.24 & $3,080,000$ \\
502 & Base of Mammoth & 81.32 & $3,180,000$ \\
502 & Gauss/Gilbert & 88.17 & $3,400,000$ \\
502A & Top of Nunivak & 113.20 & $4,080,000$ \\
502A & Base of Nunivak & 116.40 & $4,210,000$ \\
502 & Base of Gilbert C 1 & 123.26 & $4,430,000$ \\
502A & Base of Gilbert C 2 & 131.25 & $4,710,000$ \\
503B & Brunhes/Matuyama & 10.83 & 730,000 \\
503B & Base of Jaramillo & 13.33 & 980,000 \\
503B & Matuyama/Gauss & 49.20 & $2,480,000$ \\
503B & Top of Kaena & 63.60 & $2,920,000$ \\
503B & Base of Mammoth & 66.84 & $3,180,000$ \\
503B & Gauss/Gilbert & 72.45 & $3,400,000$ \\
503B & Top of Cochiti & 93.70 & $3,860,000$ \\
\hline & & &
\end{tabular}

Table 2. Numbers $(\mathrm{N})$ and periodicities $(\mathrm{P})$ of S- and C-cycles from Sites 502 and 503.

\begin{tabular}{|c|c|c|c|c|c|c|c|c|c|}
\hline & \multirow{3}{*}{$\begin{array}{l}\text { Segment } \\
\text { (m.y.) }\end{array}$} & \multicolumn{4}{|c|}{ Site 502} & \multicolumn{4}{|c|}{ Site 503} \\
\hline & & \multicolumn{2}{|c|}{ S-cycles } & \multicolumn{2}{|c|}{ C-cycles } & \multicolumn{2}{|c|}{ S-cycles } & \multicolumn{2}{|c|}{ C-cycles } \\
\hline & & $\mathrm{N}$ & P* & $\mathrm{N}$ & $\mathrm{P}^{*}$ & $\mathrm{~N}$ & P* & $\mathrm{N}$ & P* \\
\hline \multirow{4}{*}{ Quaternary } & $0-0.5$ & 4.5 & 111.0 & 10 & 50 & 4 & 125.0 & (6) & (58.0) \\
\hline & $0.5-1.0$ & 4.5 & 111.0 & 12 & 41.5 & 3.5 & 143.0 & 9 & 55.5 \\
\hline & $1.0-1.5$ & 5.5 & 91.0 & 13 & 38.5 & 6.5 & 77.0 & 12 & 41.5 \\
\hline & $1.5-2.0$ & 7.5 & 66.5 & 15 & 33.5 & 4 & 125.0 & 12 & 41.5 \\
\hline Late & $2.0-2.5$ & 8.5 & 59.0 & 12 & 41.5 & 4 & 125.0 & 11 & 45.5 \\
\hline Pliocene & $2.5-3.0$ & 4 & 125.0 & 10 & 50.0 & 5 & 100.0 & 11 & 45.5 \\
\hline \multirow{4}{*}{$\begin{array}{c}\text { Early } \\
\text { Pliocene }\end{array}$} & $3.0-3.5$ & 5 & 100.0 & 10 & 50.0 & 6 & 83.0 & 9 & 55.5 \\
\hline & $3.5-4.0$ & 5.5 & 91.0 & 12 & 41.5 & 5 & 100.0 & 14 & 35.5 \\
\hline & $4.0-4.5$ & 3.5 & 143.0 & 14 & 35.5 & 7 & 71.5 & (8) & (29.0) \\
\hline & $4.5-5.0$ & 3.5 & 143.0 & 9 & 55.5 & - & - & (7) & (21.5) \\
\hline \multirow{5}{*}{$\begin{array}{c}\text { Late } \\
\text { Miocene }\end{array}$} & $5.0-5.5$ & 5.0 & 100.0 & 11 & 45.5 & - & - & - & - \\
\hline & $5.5-6.0$ & 5.5 & 91.0 & 10 & 50.0 & - & - & - & - \\
\hline & $6.0-6.5$ & 2 & 250.0 & (10) & $(50.0)$ & - & - & (12) & (37.5) \\
\hline & $6.5-7.0$ & 3.25 & 154.0 & 11 & 45.5 & - & - & - & - \\
\hline & $7.0-7.5$ & - & - & (6) & (83.5) & - & - & (13) & (38.5) \\
\hline
\end{tabular}

Note: $*$ = values in $\mathrm{k} . \mathrm{y}$, and rounded off to nearest $0.5 \mathrm{k} . \mathrm{y}$. Parentheses indicate intervals where no-recovery gaps occurred within the $0.5-\mathrm{m} . \mathrm{y}$. segment so that values were determined from continuous sections shorter than 0.5 m.y.

cene have periods that range from 91 to $250 \mathrm{k}$.y. (average $=149 \mathrm{k} . \mathrm{y}$.) and C-cycles have a period of 45 to 50 k.y. The average carbonate content increases with time so that the lower Pliocene section has an average carbonate content of about $40 \%(\sigma= \pm 10 \%)$. There is no statistically significant change in average amplitude from the late Miocene to early Pliocene. S-cycles during the early Pliocene have periods that range between 91 and 143 k.y. (average $=119$ k.y.) whereas C-cycles have periods between 35 and 55 k.y. (average $=45$ k.y.). A change in the overall preservation of carbonate occurs in the lower Pliocene section. Carbonate in the section older than about $4 \mathrm{~m}$.y. shows moderate preservation, but the section younger than $4 \mathrm{~m}$.y. has good preservation (see site chapter, Site 502). This may have some in- 


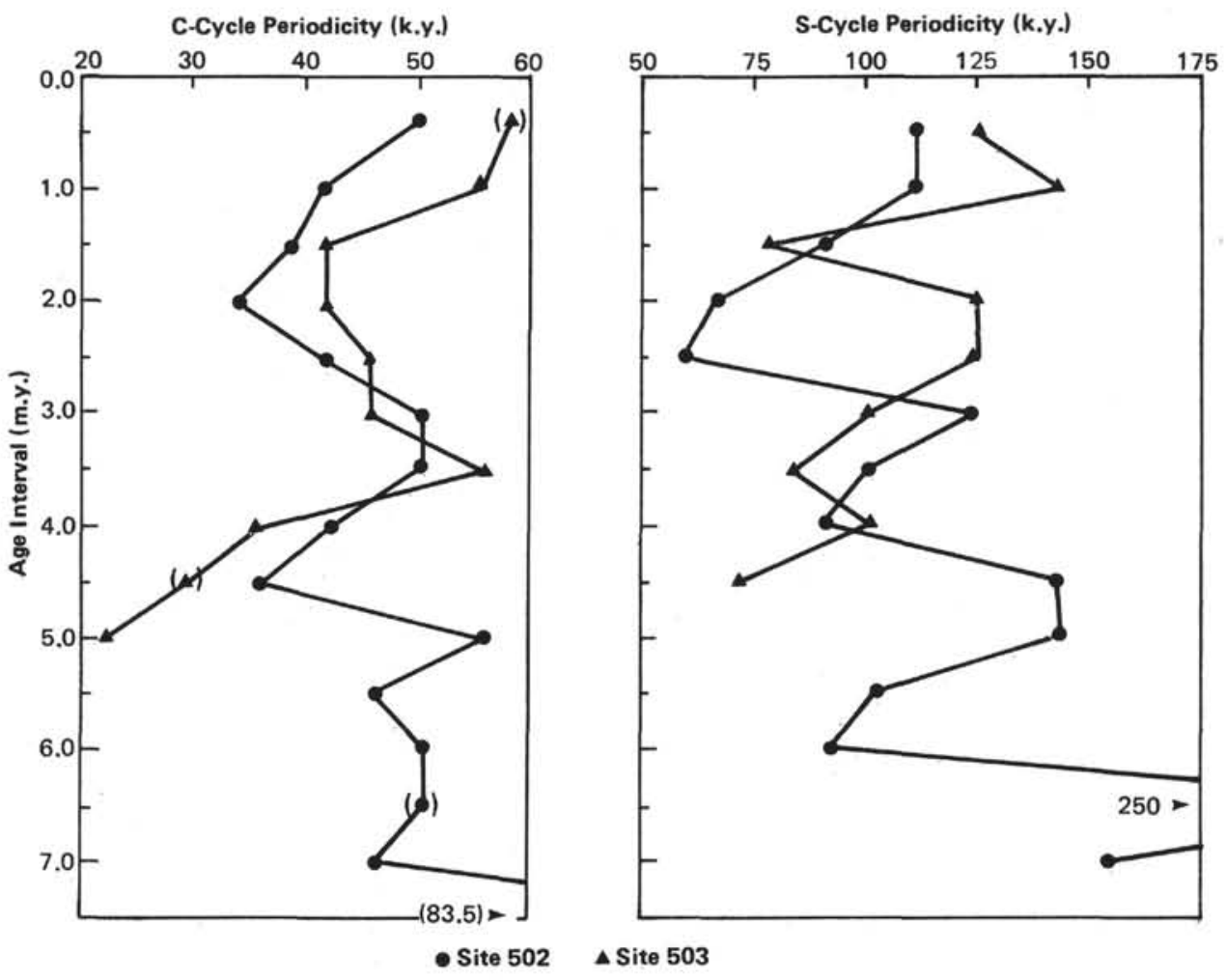

Figure 6. Plots of the periodicities of S- and C-cycles for Sites 502 and 503. (The points represent average periodicities for 0.5 m.y. intervals. Data are tabulated in Table 2.)

Table 3. Average and one standard deviation $(\sigma)$ for carbonate and organic carbon contents of time- and magnetostratigraphic intervals at Sites 502 and 503.

\begin{tabular}{|c|c|c|c|c|c|}
\hline \multirow[b]{2}{*}{ Site } & \multirow{2}{*}{$\begin{array}{l}\text { Time- and Magneto- } \\
\text { stratigraphic Interval }\end{array}$} & \multicolumn{2}{|c|}{$\% \mathrm{CaCO}_{3}$} & \multicolumn{2}{|c|}{$\begin{array}{c}\% \text { Organic } \\
\text { Carbon }\end{array}$} \\
\hline & & av. & $\sigma$ & av. & $\sigma$ \\
\hline \multirow[t]{10}{*}{502} & Quaternary & 48.4 & 7.3 & 0.41 & 0.15 \\
\hline & Late Pliocene & 50.6 & 5.5 & - & - \\
\hline & Early Pliocene & 40.1 & 10.1 & - & - \\
\hline & Pliocene & 44.3 & 9.9 & - & - \\
\hline & Late Miocene & 27.7 & 11.6 & - & - \\
\hline & Brunhes & 48.5 & 6.6 & 0.40 & 0.18 \\
\hline & Matuyama & 49.0 & 7.1 & 0.14 & 0.21 \\
\hline & Gauss & 49.2 & 5.2 & - & - \\
\hline & Gilbert & 40.4 & 9.8 & - & - \\
\hline & Pre-Gilbert & 26.4 & 10.4 & - & - \\
\hline \multirow[t]{9}{*}{503} & Quaternary & 45.7 & 16.9 & 0.46 & 0.23 \\
\hline & $\begin{array}{l}\text { Late Pliocene } \\
\text { Early }\end{array}$ & 39.7 & 14.0 & 0.46 & 0.28 \\
\hline & Pliocene & 43.4 & 16.7 & 0.33 & 0.19 \\
\hline & Pliocene & 42.4 & 16.1 & 0.36 & 0.22 \\
\hline & Late Miocene & 52.6 & 13.5 & - & - \\
\hline & Brunhes & 55.4 & 15.5 & 0.42 & 0.20 \\
\hline & Matuyama & 40.0 & 15.1 & 0.46 & 0.27 \\
\hline & Gauss & 43.3 & 13.3 & 0.41 & 0.20 \\
\hline & Pre-Gauss & 48.3 & 16.8 & 0.15 & 0.20 \\
\hline
\end{tabular}

fluence on the periodicities and certainly has an influence on the amplitudes of the cycles.

The upper Pliocene section has an average carbonate content of about $50 \%(\sigma= \pm 5 \%)$ and the amplitudes of carbonate cycles are considerably reduced relative to those in the lower Pliocene section. The trend in average carbonate content is constant throughout the upper Pliocene and stays constant from about $3.5 \mathrm{~m} . \mathrm{y}$. to about 200 k.y. S-cycles in the upper Pliocene section have periodicities that range from 59 to $125 \mathrm{k} . \mathrm{y}$. (average $=92 \mathrm{k} . \mathrm{y}$.) and C-cycles range between 41 and $50 \mathrm{k} . \mathrm{y}$. (average $=45$ k.y.). Average carbonate content in the Quaternary section is about $48 \%(\sigma= \pm 7 \%)$. The amplitudes of carbonate content in the Quaternary section are statistically greater than those of the Pliocene. The periodicities of the S-cycles in the Quaternary section vary between 66 and 111 k.y. (average $=95$ k.y.) and C-cycles have periods between 33 and 50 k.y. (average $=41$ k.y.).

\section{Description of the Organic Carbon Record}

Organic carbon was determined only for the Quaternary section at the U.S. Geological Survey (USGS) Marine Sediments Lab and for the late Neogene at the DSDP laboratory. Although both laboratories used similar analytical techniques, the amplitudes of the organic carbon contents from the two different data sets are noticeably different. Initial replicate samples and laboratory intercalibrations suggest that these differences are real and not analytical differences. However, until this can be vigorously tested, the late Neogene section will be presented but not interpreted. The data suggest that there are cyclic fluctuations of organic carbon accumulation for the Quaternary on at least two periodicities (Fig. 7A). Large-scale cycles with periods of about $500 \mathrm{k} . \mathrm{y}$. have cycles with periods of about $60 \mathrm{k} . \mathrm{y}$. superimposed on them. The average content of organic carbon is $0.41 \%(\sigma=$ $\pm 0.15 \%$ ). The organic carbon record shows cycles that 
may correspond to C-cycles of the carbonate record but nothing that correlates with the S-cycles.

\section{CARBONATE STRATIGRAPHY AT SITE 503}

\section{Description of the Carbonate Record}

The general trend of the carbonate record at Site 503 consists of a long-wavelength fluctuation with a period of approximately $600 \mathrm{k} . \mathrm{y}$. that changes, at the early-late Pliocene boundary, to a wavelength of about 500 k.y. (Fig. 5B, back pocket, this volume). S- and C-cycles from Site 503 have periods similar to those at Site 502 (Table 2 and Fig. 6). The S-cycles in the Site 503 data are defined as portions of the data between high concentrations of carbonate, not between low concentrations as is the case for the Site 502 record. This is done because of the well-established polarity reversal of Quaternary carbonate responses of the Atlantic (Caribbean), relative to the Pacific, to global climatic changes. This reversal in response may not hold for the pre-upper-Pliocene section. Dunn et al. (1980) suggested that the Atlantic and Pacific may have had a similar carbonate response prior to the emergence of the Isthmus of Panama. I have chosen to define the S-cycles using the reverse relationship mainly because the majority of my continuous data occur in the 0 to 4.5 m.y. interval.

The upper Miocene section has an average carbonate concentration of $53 \%(\sigma= \pm 13 \%)$. The approximate 600 k.y. cycle is readily apparent (Fig. 5B), even though several intervals were not recovered. Average carbonate content increases through Chron 7 with several highamplitude changes $\left(\sim 50 \% \mathrm{CaCO}_{3}\right)$. The average carbonate content throughout Chron 6 is relatively constant at about $40 \%$; total variations are about $30 \%$ and are lower than those in Chron 7. There are too few data points in the Chron 5 interval to allow definition of cycles. The average periodicity for C-cycles of late Miocene age is about 38 k.y. The lower Pliocene section shows periodicities of C-cycles between 21 and 55 k.y. (average $=35 \mathrm{~m} . \mathrm{y}$.) and the carbonate peaks are very abrupt with amplitudes of $50 \%$ carbonate. The early Pliocene S-cycles have periods of 70 to 100 k.y. (average $=85$ k.y.) and an average carbonate content of $43 \%$ $(\sigma= \pm 17 \%)$. Nothing more can be said for the lower portion of this section because of the occurrence of numerous no-recovery gaps. Average carbonate content decreased during the late Gilbert chronozone to very low values 3.6 to $3.7 \mathrm{Ma}$. Carbonate then increased somewhat into the lower Gauss Chron but with no change in amplitude. The upper Pliocene section has intervals of very low carbonate content between 2.4 and $2.45 \mathrm{Ma}$ and at $1.92 \mathrm{Ma}$. The average concentration of carbonate in the upper Pliocene part of the section is $40 \%(\sigma= \pm 14 \%)$. C-cycles during the late Pliocene have periods of $45.5 \mathrm{k} . \mathrm{y}$. and the variance of the amplitudes are statistically similar at the $5 \%$ level of significance to those of the lower Pliocene part of the section. Carbonate concentrations in the Quaternary section average $46 \%(\sigma= \pm 17 \%)$. There is an interval of lower than average carbonate content from 700 to 850 k.y. ago. C-cycles have amplitude fluctuations that are simi- lar to those in the lower Pliocene section, but they are statistically different from those in the upper Pliocene. The periodicities of C-cycles during the Quaternary range between 41 and 58 k.y. (average $=49$ k.y.). A change in frequency and amplitude of C-cycles at about $1 \mathrm{Ma}$ is readily apparent from Figure $5 \mathrm{~B}$ and matches the observations of Shackleton and Opdyke (1976) and Prell (this volume) of a similar change at that time in the oxygen-isotope record.

\section{Description of the Organic Carbon Record}

Figure 7B is a plot of organic carbon versus age for the composite section at Site 503. All of these data were generated at the USGS Marine Sediments Lab. The average concentration of organic carbon increases from the lower Pliocene through the Holocene section. No analyses were made of upper Miocene sediment. The amplitudes of variations of organic carbon increase with increasing average organic carbon content, and they are statistically different (at the $5 \%$ level of significance) between the lower Pliocene, upper Pliocene, and Quaternary parts of the section. There is a strong negative correlation between carbonate and organic carbon at Site 503 which will be discussed later.

\section{DISCUSSION}

\section{Possible Causes of the Carbonate Fluctuations}

The possible causes of cyclic variations in carbonate content through time can be categorized under three basic mechanisms: dilution by noncarbonate material, dissolution of carbonate material, and changes in the rate of supply of carbonate material. These three mechanisms and their influence have been discussed by Gardner (1975), Dean et al. (1977), and Dean et al. (1981), among others, and will not be reviewed in detail here. But a brief discussion is necessary, especially in view of the very different settings of the two sites.

The rate of supply of carbonate material, that is, biogenic carbonate productivity, is the most difficult mechanism of the three to quantify. Concentrations of carbonate and silica can be postdepositionally altered by dissolution thereby obliterating any productivity signal. Although organic carbon might appear to be an indicator of biogenic productivity, studies by Heath et al. (1977) and Muller and Suess (1979) suggest that organiccarbon input by primary production is overwhelmed by the bulk accumulation of sediment. They estimate that only $0.01 \%$ of the primary-produced organic carbon is preserved in sediment. We are therefore left with the option of holding productivity constant and investigating changes in the other two variables.

Dilution by noncarbonate material has been demonstrated as a mechanism for reducing the carbonate concentration (Gardner, 1975; Diester-Haass, 1976; Chamley, et al., 1977). The amount of dilution necessary to reduce an initial carbonate content $\mathrm{C}_{\mathrm{i}}$ to some observed carbonate value $C_{f}$ can be calculated using the equation of Gardner (1975):

$$
\text { Addition }=\left[\left(C_{i} / C_{f}\right)-1\right] /\left(1-C_{i}\right) \text {. }
$$




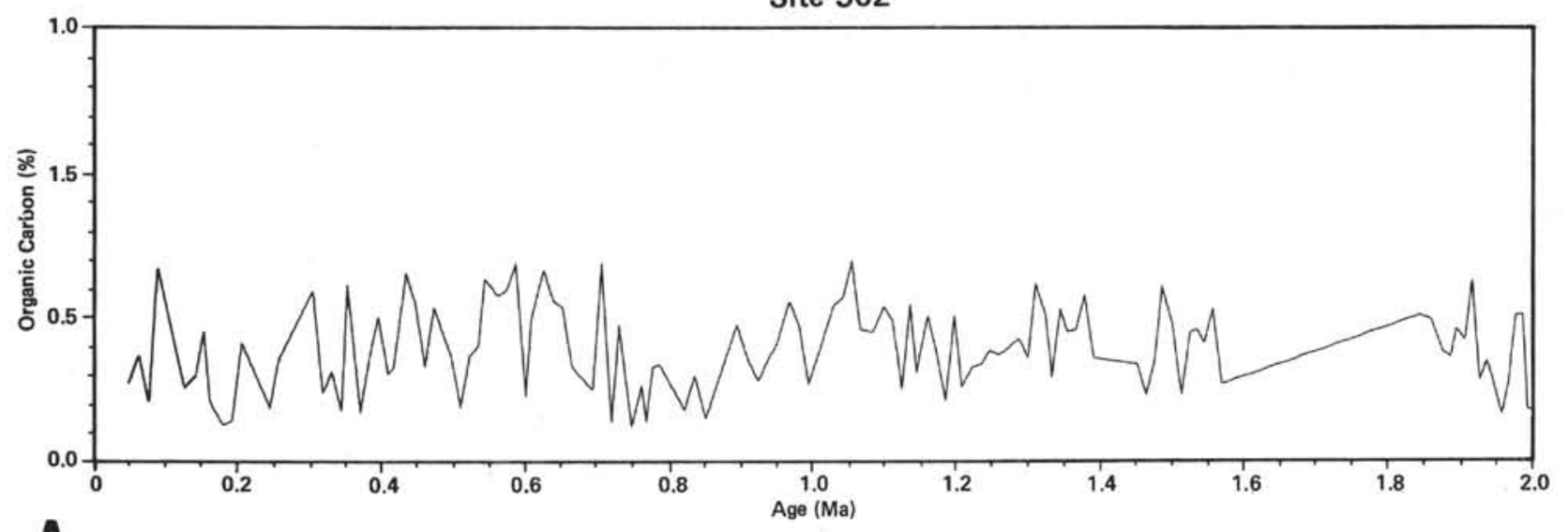

A
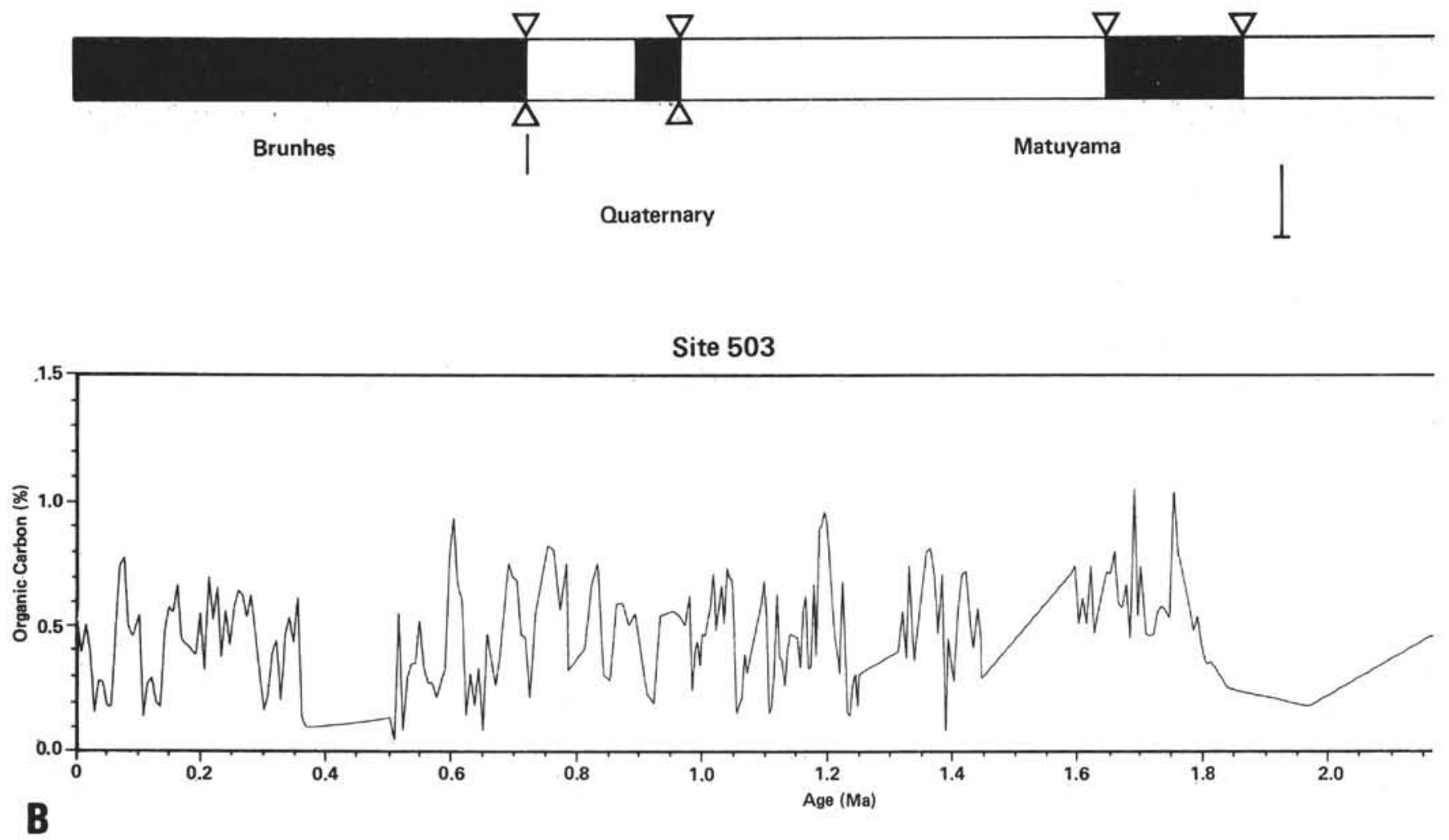

Figure 7. A. Organic carbon versus age for Site 502. B. Organic carbon versus age for Site 503. 

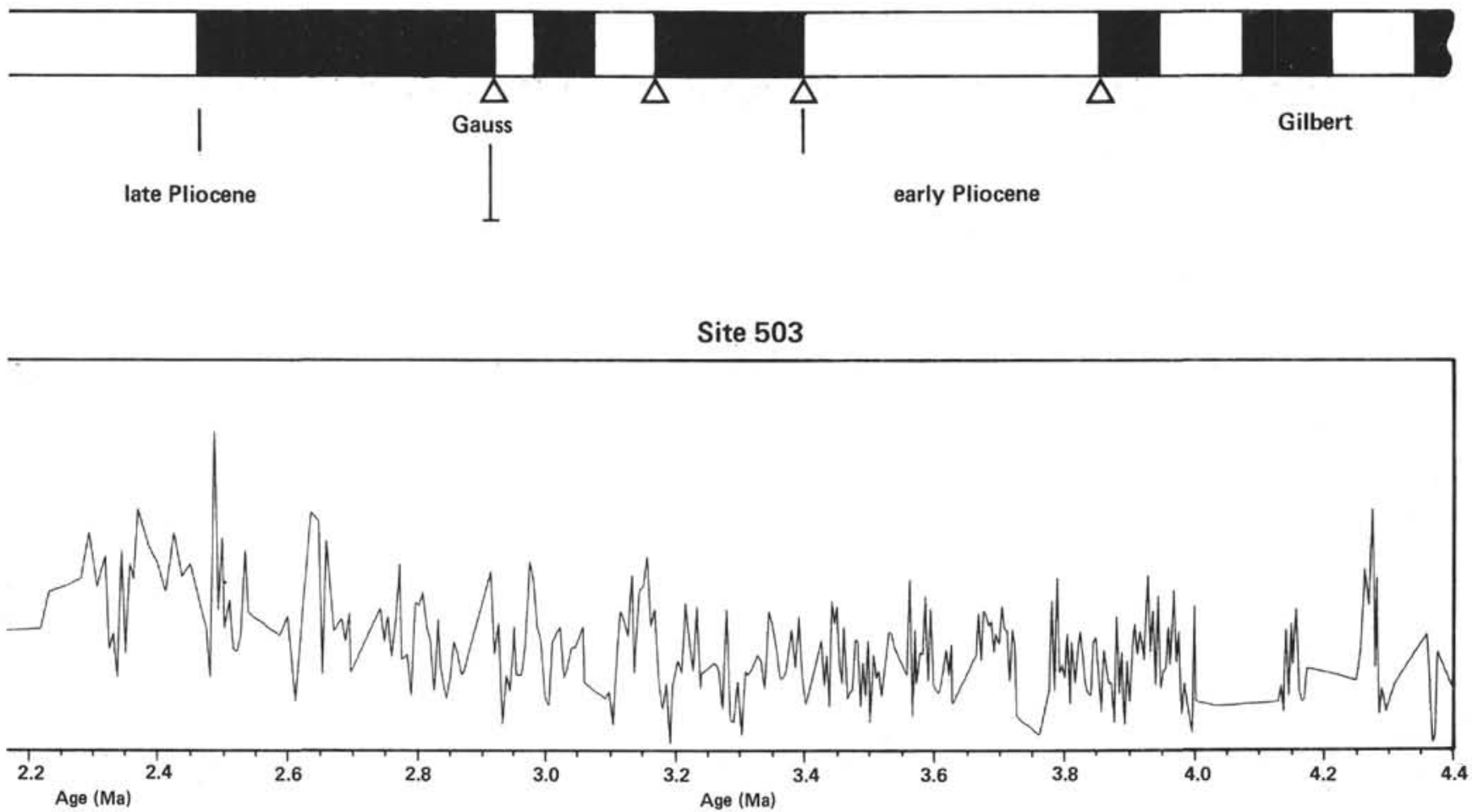

Figure 7. (Continued). 


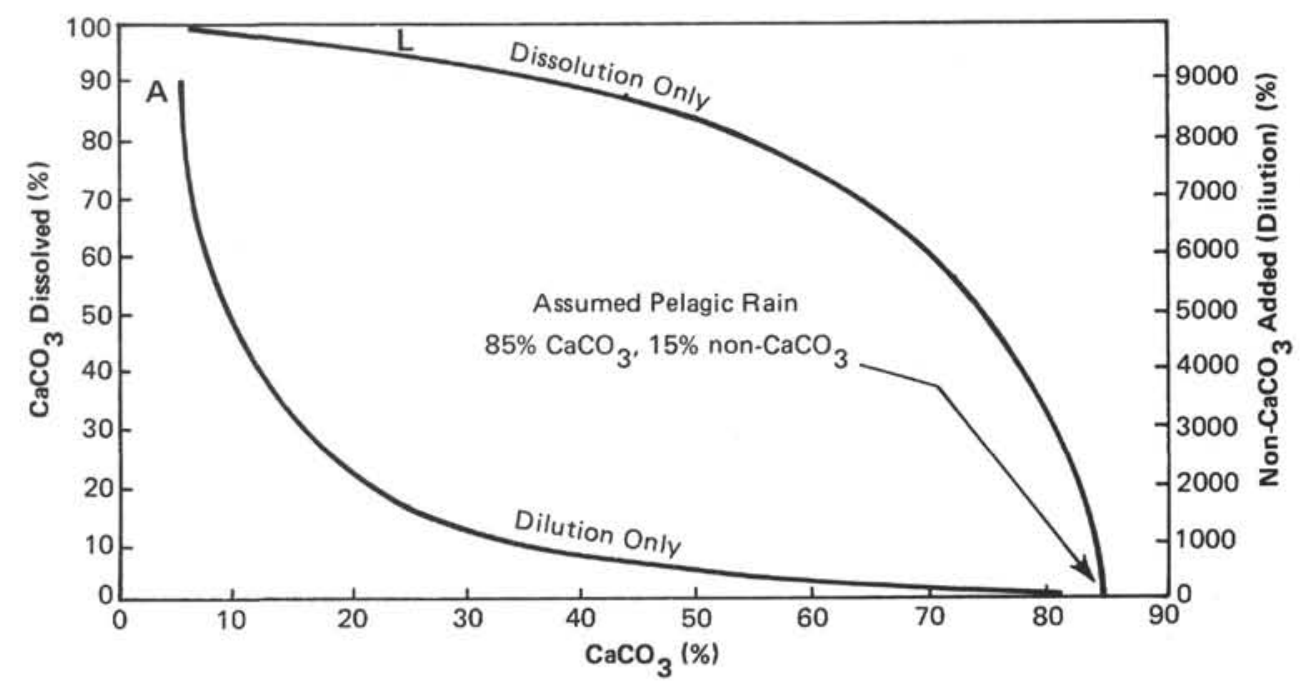

Figure 8. Curves for loss of carbonate by dissolution (L) and addition by dilution (A) to an initial sediment rain composed of $85 \%$ carbonate and $15 \%$ noncarbonate material (after Dean et al., 1981). (See text for explanation.)

A curve of this equation is labeled $\mathrm{A}$ in Figure 8. The curve shows that it takes a large amount of noncarbonate material to significantly reduce carbonate content. For example, if "sediment rain" at a locality had a composition of $85 \%$ carbonate and $15 \%$ noncarbonate, it would require a $470 \%$ increase in noncarbonate to produce an observed carbonate content of $50 \%$. Increases in sediment influx of this order would be reflected in the bulk accumulation rates.

Dissolution of carbonate is the other mechanism often discussed to account for the fluctuations in carbonate content (Berger, 1968, 1973; Hays et al., 1969; Thompson and Saito, 1974; Gardner, 1975; Dean et al., 1981; among others). The mechanism involves fluctuations of the lysocline and CCD through increased production or corrosiveness of bottom waters. Dissolution can be treated just as dilution was, using the equation of Gardner (1975):

$$
\text { Loss }=\left[1-\left(\mathrm{N}_{\mathrm{i}} / \mathrm{N}_{\mathrm{f}}\right)\right] /\left(1-\mathrm{N}_{\mathrm{i}}\right)
$$

where $\mathrm{N}_{\mathrm{i}}$ is the initial noncarbonate value that was increased to $\mathrm{N}_{f}$, the observed noncarbonate concentration. The curve labeled L in Figure 8 reflects the required percentage decrease using the same initial conditions discussed above. In the dissolution model, $82 \%$ of the original carbonate must be dissolved to reduce the carbonate content from $85 \%$ to $50 \%$. Probably, some subtly complicated combination of changes in carbonate production, dissolution, and dilution all contribute to an observed carbonate record. However, the lithofacies of the sediment (hemipelagic versus pelagic) can suggest whether dilution or dissolution was the dominant process.

\section{Causes of Carbonate Fluctuations at Site $\mathbf{5 0 2}$}

The overall trend of carbonate as well as the hemipelagic facies preserved at Site 502 reflects in part the tectonic uplift of the horst out of the influence of terrig- enous input, thus a dilution signal. Figure 3 clearly shows the tectonic setting for Site 502 and its relation to Site 154 . The strong reflector at about 0.6 -s sub-bottom (two-way travel time) may correspond to the volcanogenic turbidites of late Miocene and early Pliocene age recovered at Site 154 (Edgar et al., 1973). However, this reflector may be much older. Site 502 penetrated just to the faint reflector at about 0.3 -s sub-bottom that marks the base of the acoustically transparent section. The basal sediment (234-m sub-bottom) at Site 502 is upper Miocene hemipelagic clay. Site 154 encountered volcanogenic turbidites at 153 meters sub-bottom. Consequently, it is more likely that the volcanogenic turbidites recovered at Site 154 correlate to the faint reflector at $0.3 \mathrm{~s}$ sub-bottom. Also, this comparison suggests that Site 502 was uplifted at a faster rate than was Site 154 . One of the effects of this uplift on the carbonate record was the gradual increase of average carbonate accumulation from 7.5 Ma up to about 3.8 Ma. This presumably reflects the elevation of Site 502 from a position where it received a significant component of terrigenous clay from southern central America and northern South America to a position where it received lesser amounts of clay. The long-period $500 \mathrm{k} . \mathrm{y}$. cyclic record can either be interpreted as a slow fluctuation of source material or of some oceanic circulation that fluctuated on a long time scale. Dissolution does not seem to be the major factor in the carbonate record; preservation of biogenic carbonate is generally good to moderate (see site chapter, Site 502, this volume). However, the change in the preservation of carbonate at about 4 Ma may reflect the elevation of Site 502 from a position within the lysocline to a position above the top of the lysocline. This is consistent with the suggestion of Ramsay (1977) that the lysocline in the Caribbean was depressed from a 2000meter depth at $8 \mathrm{Ma}$ to 3900 meters about 1 to $3 \mathrm{Ma}$. The present water depth at Site 502 is 3051 meters. Consequently, there may be a dissolution signal within the carbonate record and possibly the 500 k.y. cycle is a record of fluctuations of the lysocline. 
The timing of the change in preservation of carbonate also roughly coincides with estimates of 3.2 to 3.6 m.y. for the emergence of the Isthmus of Panama (Kaneps, 1970; Keigwin, 1978). This coincidence suggests that as the Caribbean changed from a broad oceanic seaway to a marginal sea, circulation responded so as to isolate the Caribbean from the Pacific. The late Miocene and early Pliocene may have been times when strong zonal circulation occurred from the Atlantic to the Pacific. Certainly, the Antilles Ridge today poses a barrier to broad-scale circulation, but in the early Neogene this may not have been the case. However, the data concerned with the Antilles are at times contradictory. Fox et al. (1971) suggested that Aves Ridge, a northsouth ridge to the west of the Antilles Ridge, was a shallow marine feature from middle Eocene to early Miocene, but submerged to bathyal depths in middle Miocene. Tomblin (1975) suggests that the lesser Antilles island arc was subaerial during the Eocene and Oligocene, shallow marine during the Miocene, and subaerial during the Pliocene and Quaternary. Donnelly (1975) pointed out that pre-lower-Miocene siliceous sediment in the Caribbean can be correlated with similar facies in the Gulf of Mexico and Atlantic. He concludes, "thus the Antillean island chain formed at this time no effective barrier to Pacific-Caribbean siliceous surface waters." The more apparent conclusion is that the Antillean island arc formed at this time no effective barrier to Atlantic-Caribbean surface waters. However, even these observations and speculations do not address the question of deep circulation between the Atlantic and Caribbean in the early Neogene. Dunn et al. (1980) suggested that upper Miocene equatorial Pacific sediment preserved an "Atlantic type" carbonate stratigraphy that is opposite to the Pleistocene response. This is the first evidence to suggest that Atlantic deep-water masses penetrated through the Caribbean and into the Pacific during that time and that the Atlantic and Pacific were in phase with respect to response of carbonate to dissolution events. They further suggest that the emergence of the Isthmus of Panama may mark the time when carbonate of the equatorial Pacific switched from an "Atlantic type" to a "Pacific type" response. That reversal of response may actually have occurred around $4 \mathrm{Ma}$, 500 k.y. before the actual emergence of the isthmus.

S-cycles at Site $\mathbf{5 0 2}$ have periodicities similar to those found in other Quaternary sequences-the approximate 100 k.y. periodicities that prompted Hays et al. (1976) to speculate that they had uncovered the "pacemaker of the ice ages." The periodicities of the S-cycles were determined by a totally different technique from that used by Hays et al. (1976), and therefore differences might be expected, but certainly the range of periodicities is similar to theirs. Periodicities similar to the S-cycles have been reported in numerous studies. For instance, Emiliani (1978) shows oxygen-isotope data that have a wavelength of 122 k.y.; Hays et al. (1976) and Briskin and Harrel (1980) found sea-surface temperature estimates and oxygen-isotope fluctuations with dominant periods of about 24,43 , and $105 \mathrm{k} . \mathrm{y}$. The periodicities of the Scycles are similar to those attributed to global climatic changes and are not outside the range of the period of the eccentricity of the Earth's orbit (Milankovitch, 1930; Anderson, 1964; Broecker and Van Donk, 1970; Hays et al., 1976; Berger, 1977, 1979).

What has been pointed out above for the S-cycles can be stated equally for the periodicities of the C-cycles. Periodicities between 40 and 60 k.y. have been discussed by Broecker and Van Donk (1970), Hays et al. (1976), Dean et al. (1977, 1981), Berger (1977), Mesolella et al. (1969), and Briskin and Harrell (1980), among others. This range of periodicities most closely correlates to the obliquity cycles of the Earth's orbit. However, a discussion by Kominz and Pisias (1979) is worth noting. They cautioned that although there may appear to be a relationship between cyclic accumulation of sediment, predicted parameters based on components within sediment, and Earth's orbital parameters, a large component of the sediment record affected by climatic variation may be the result of other, more random, factors.

\section{Causes of Carbonate Fluctuations at Site $\mathbf{5 0 3}$}

The initial study that identified cyclic carbonate accumulations in the Pacific was that of Arrhenius (1952). $\mathrm{He}$ correlated high abundances of carbonate with glacial stages, reasoning that equatorial upwelling during glacial stages would effect an increase in productivity and thus an increase in carbonate flux to the seafloor. The increased flux to the seafloor would also inhibit dissolution by rapid burial. His initial arguments were those of changing productivity, but he later suggested that dissolution might be a major factor (Arrhenius, 1963). Hays et al. (1969) showed, in a sequence of Pacific cores from progressively deeper depths, that the maximum concentrations of carbonate from shallower cores is greater than from deeper cores. This observation, together with the fact that the lower carbonate zones were noticeably lacking in dissolution-susceptible species of planktonic foraminifers, started a series of studies that most workers agree confirm the dissolution model for the equatorial Pacific.

The pelagic lithofacies of sediment from Site 503, its location far removed from any significant source of terrigenous dilution, as well as its present depth within the lysocline, all strongly argue for dissolution as the principal mechanism for the cause of the cyclic accumulation of carbonate. The trade winds can transport significant quantities of material (see Rea, this volume), as can volcanic eruptions. In fact, volcanic glass is fairly ubiquitous but in rare abundances throughout the sediment section (see site chapter, Site 503; Ledbetter, this volume). However, biogenic components are the dominant constituents of the lithofacies.

Site 503 is located on the north flank of Galapagos Ridge. The acoustic section is subtly stratified (Fig. 9), and the lithofacies alternate between nannofossil ooze and siliceous nannofossil ooze throughout the 240-meter thickness. The data of Hey (1977) indicate that if Site 503 is backtracked, then its location changes less than $2^{\circ}$ of latitude. However, the depth of Site 503 has progressively deepened with time from possibly less than 1000 meters to its present 3682-meter depth. Curves pre- 


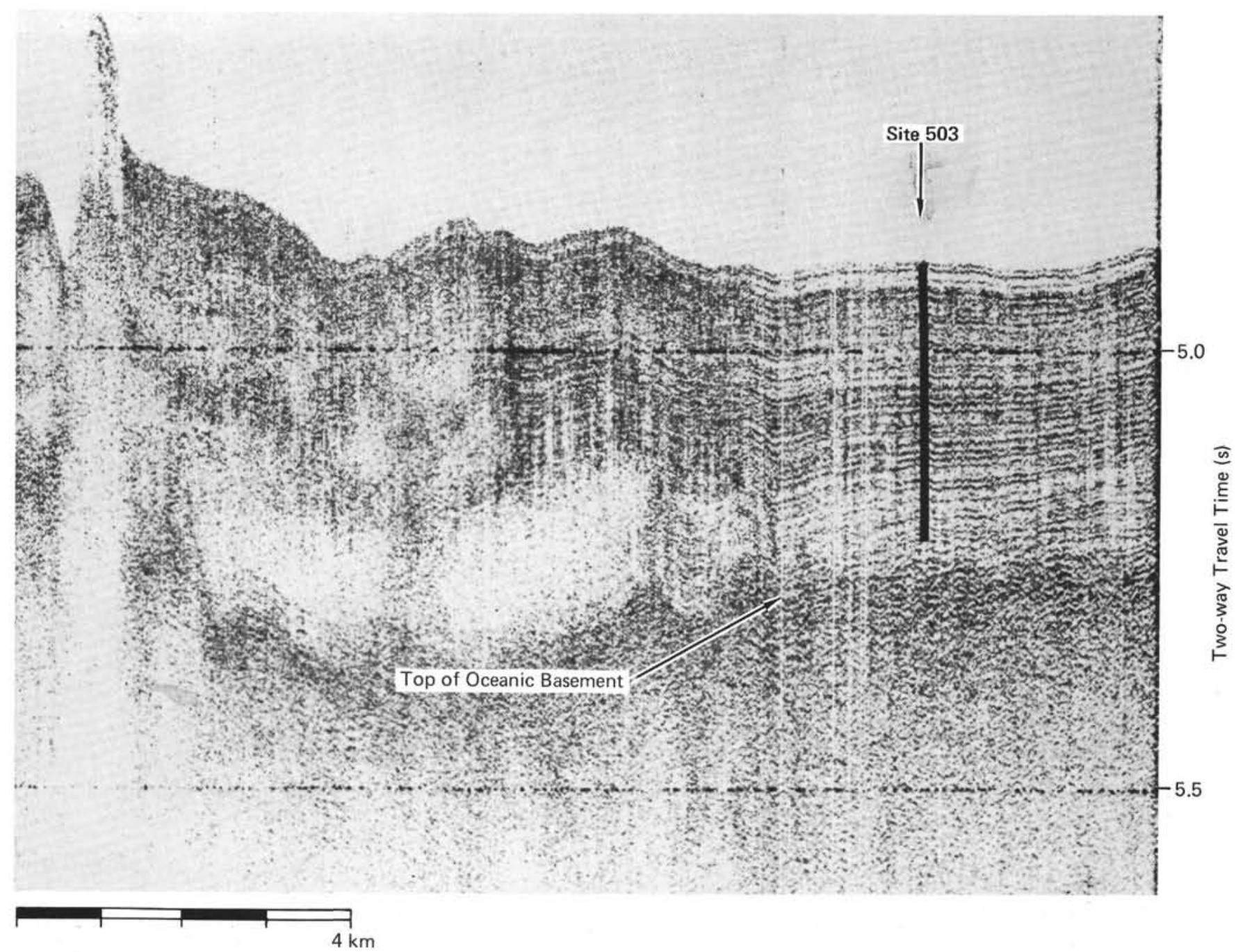

Figure 9. GC-68 seismic-reflection profile across Site 503. The maximum penetration at Site 503 was approximately $10 \mathrm{~m}$ above the top of oceanic basement.

sented by van Andel et al. (1975) suggest that the equatorial CCD has been depressed from a late Miocene depth of about 4700 meters to a Holocene depth of about 4900 meters. The carbonate record at Site 503 indicates that the sediments were never below the CCD (the depth on the seafloor where no carbonate is preserved), but they were affected by fluctuations of the lysocline. Preservation patterns of microfossils show that both planktonic foraminifers and nannofossils reflect variations in dissolution effects, but the carbonate stratigraphy does not show any monotonic trends that would suggest a progressive change in dissolution of carbonate with time. Evidently, Site 503 maintained a position within the lysocline as it subsided. The range of periodicities of both S- and C-cycles in the section at Site 503 is similar to those found at Site 502; consequently, the same causal mechanisms most likely apply to both sites.

\section{COMPARISONS WITH OTHER RECORDS}

The oxygen-isotope record Core V28-239 (Shackleton and Opdyke, 1976) is one of the standard sequences used to delineate global climatic stages. This core is 21 meters long but has an average accumulation rate of only 1 $\mathrm{cm} / \mathrm{k}$.y. A correlation can be made between this oxygenisotope record and the carbonate records from Sites 502 and 503 (Fig. 10). Caution has been applied during these correlations because of (a) the highly unlikely probability of constant accumulation rate between paleomagnetic datums, (b) the documented lag of several thousand years of sediment-carbonate response relative to global oxygen-isotope response (Broecker, 1971; Pisias et al., 1975; Luz and Shackleton, 1975; Ninkovich and Shackleton, 1975; Shackleton and Opdyke, 1976), (c) the comparison of an oxygen-isotope record from one core to carbonate records from other cores, and (d) geographic separation of the sections-i.e., the records are from cores from different oceans.

The carbonate record at Site 503 has been correlated not only to the standard oxygen-isotope curve of V28239 from Ontong-Java Plateau in the western equatorial Pacific but also to the carbonate curve from RC11-209 from the central equatorial Pacific (Hays et al., 1969) (Fig. 10). The carbonate stratigraphy from RC11-209 has been used as a standard Pacific carbonate record 


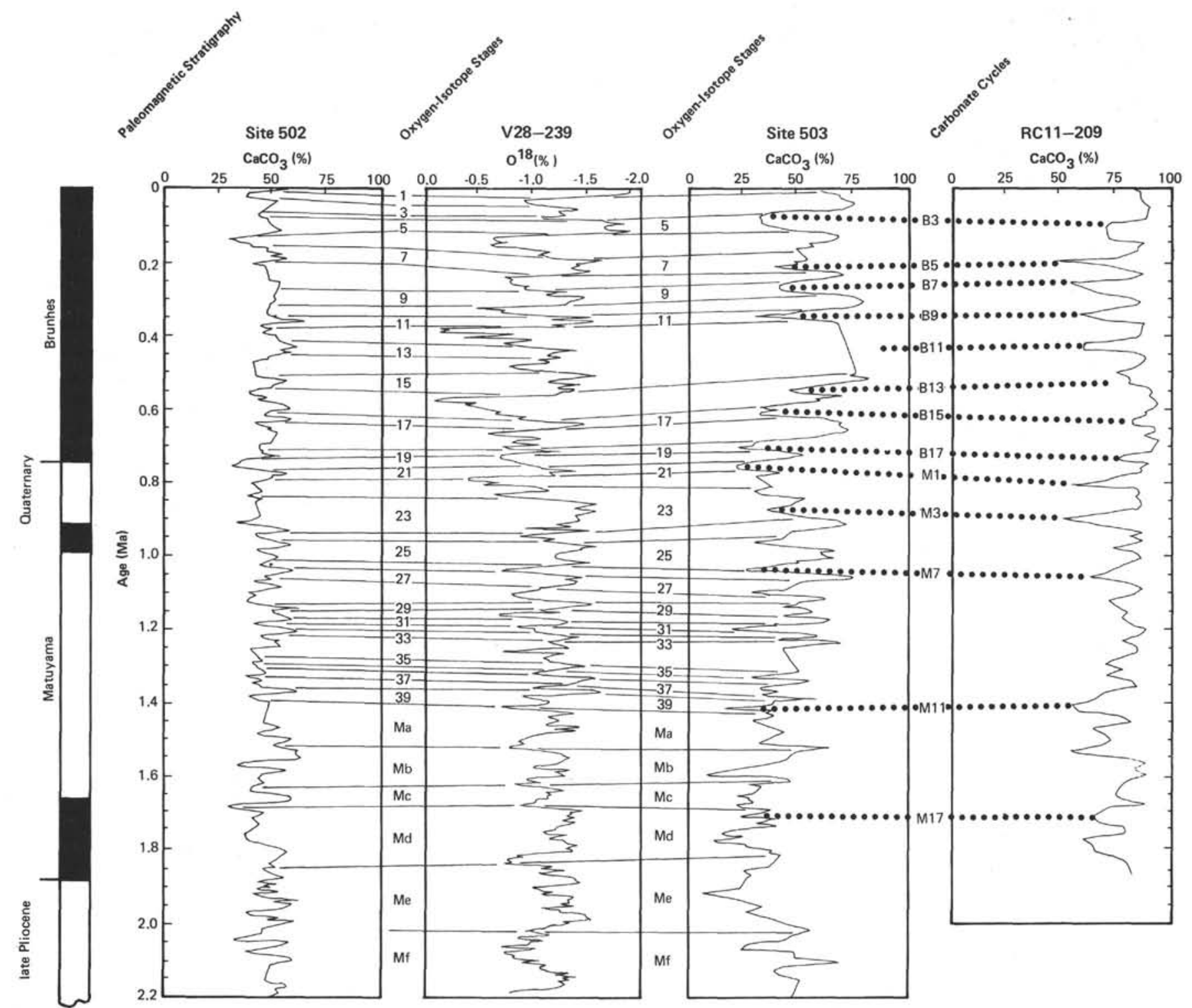

Figure 10. Correlation between carbonate stratigraphy of Site 502 and oxygen-isotope stratigraphy of V28-239 and between the carbonate stratigraphies of Site 503 and RC11-209 and the oxygen-isotope stratigraphy of V28-239. (The oxygen-isotope stages are modified from Shackleton and Opdyke [1976] and the carbonate cycles are from Hays et al. [1969].)

(Kaneps, 1973; Thompson and Saito, 1974; Vallencia, 1977; Thompson and Sciarrillo, 1978; among others). The records from V28-239 and RC11-209 are only for the last $2.2 \mathrm{~m} . \mathrm{y}$., but a correlation between these and the carbonate records at Sites 502 and 503 can be made.

In order to make an appropriate match between the carbonate record of Site 503 and the isotope record of V28-239, the "polarity" of response of Pacific carbonate sediment to global climatic conditions previously discussed must again be taken into account. Consequently, any correlation of Quaternary sections of Pacific-type carbonate curves with oxygen-isotope curves must match high carbonate values with less negative (heavier) $\delta^{18} \mathrm{O}$ values and vice versa.

Shackleton and Opdyke (1976) decided against defining isotope stages beyond Stage 23 because they felt it would be necessary to define shorter stages if they stayed with their criterion. However, they did draw in boundaries from Stage 23 through 39 . The composite records from Sites 502 and 503 can be correlated to all 23 isotope stages defined in V28-239 and the correlation can continue throughout the length of V28-239. The numbers 24 through 39 in Figure 10 are a continuation of the oxygen-isotope stage nomenclature of Shackleton and Opdyke (1976), and letters are used for the remainder of the core. Plots of the ages for carbonate maxima from Sites 502 and 503 against ages of minima on the oxygen-isotope curve of V28-239 show that the carbonate response always lags behind the oxygen-isotope response by about 1 to 5 k.y. (Fig. 11). A lag of this same sense and magnitude was predicted by Broecker (1971) and found by Shackleton and Opdyke (1976) between oxygen-isotope values and coarse-fraction values (interpreted by them as dissolution events). Luz and Shack- 

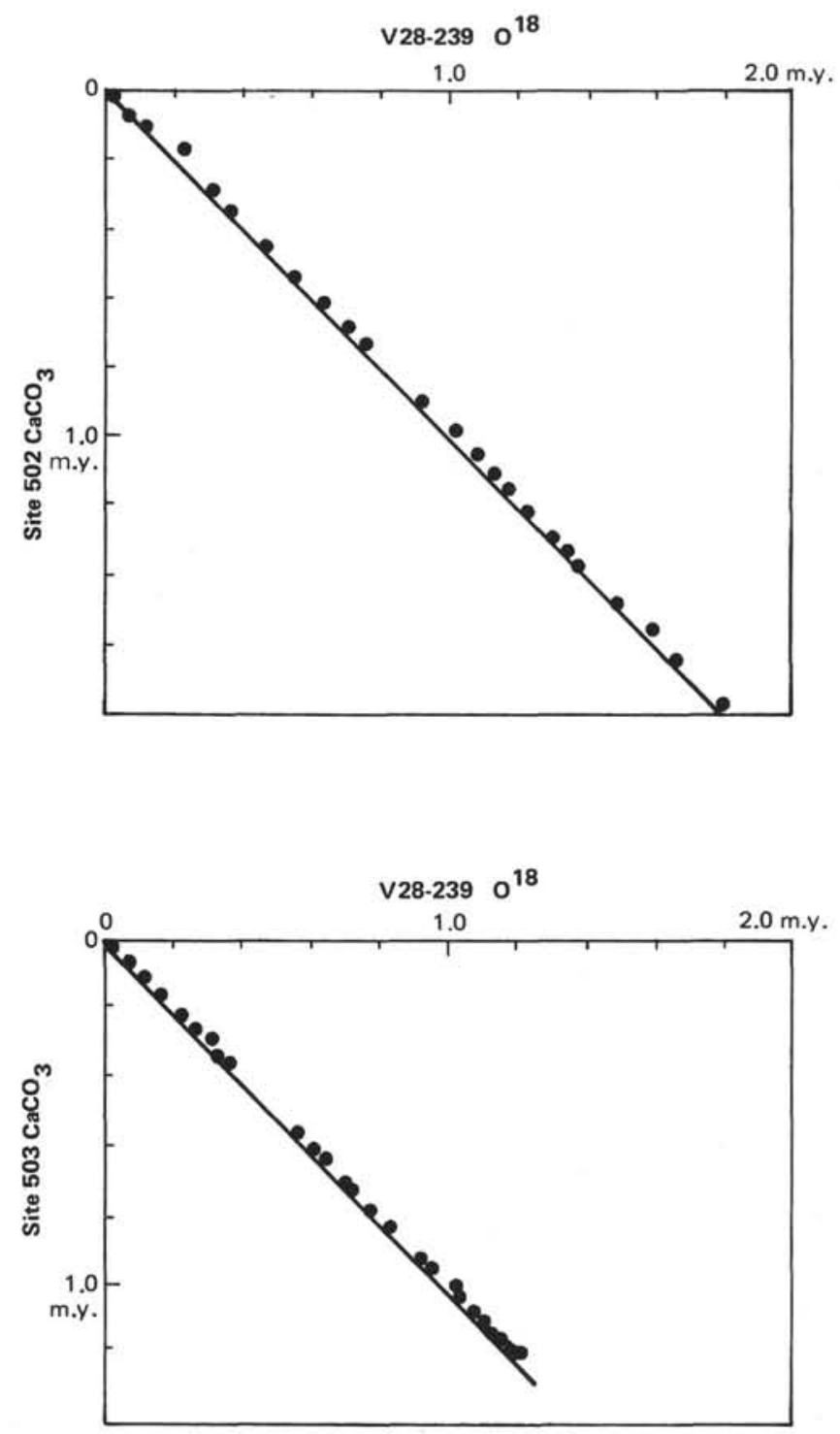

Figure 11. Plot of individual "peak" correlations of the carbonate stratigraphies of Sites 502 and 503 correlated to the corresponding zones of the oxygen-isotope stratigraphy of V28-239. (The diagonal lines represent a 1:1 regression. Notice that all "peaks" of carbonate lag behind the corresponding one for oxygen-isotope by about 1 to 5 k.y.)

leton (1975), Ninkovitch and Shackleton (1975), and Moore et al. (1977) found the same lag of carbonate behind oxygen-isotope values from Pacific cores. The oxygen-isotope response should react on a time scale of the mixing time of the oceans, i.e., on the order of 1.5 k.y. (Broecker, 1974). Dissolution of carbonate, however, involves not only the rate of increase of corrosiveness of bottom water, but also the dissolution reactionrates of calcium carbonate and mixing rates of bioturbation. All of these rates are unknown, but the empirical data suggest that the result of these rates is greater than the mixing time of the ocean by a factor of about 3 . Carbonate cycles from Site 502 are not the result of dissolution of carbonate, but rather of changes in the amounts of terrigenous material being shed into the Colombian Basin. The record from Site 502 suggests that runoff into the Caribbean increased during global glacial conditions. Low-latitude regions respond to global climatic cooling by a constriction of the north-south migration of the Intertropical Convergence Zone (Newell, 1973; Gardner and Hays, 1976). The response to climate in the areas of Central and South America that are drained by rivers flowing into the Caribbean also lagged behind the ice buildup on land by this same $10^{3}$ years. This seems reasonable because of the low latitude of the region in question.

\section{COMPARISON OF SITE 502 AND 503}

One of the primary objectives of Leg 68 was to compare the late Neogene and Quaternary histories recorded in sediment from the western Caribbean to that from the eastern equatorial Pacific to see what effects occurred from the emergence of the Isthmus of Panama and initiation of glaciation in the Northern Hemisphere. The carbonate stratigraphies provide an excellent means of comparing responses of the two oceans to global climatic changes.

The most striking difference between the two carbonate records is the amplitudes of the fluctuations: those in the carbonate record from Site 503 are much larger than corresponding changes from the record at Site 502 . The reasons for this difference are that the carbonate record from Site 503 is a dissolution signal from a location within the top of the lysocline. Therefore, small vertical movements of the lysocline appear as dramatic changes in the carbonate record (i.e., a deep lysocline allows accumulation of high-carbonate concentrations and a shallow lysocline results in the accumulation of moderate- to low-carbonate concentrations). However, the record from Site 502 is a more complicated combination of responses to fluctuations in noncarbonate dilutants produced by local tectonic sources as well as more-distant sources, such as the Rio Magdalena, all working somewhat independent of each other.

Five hundred to 600 k.y. cycles are found in the Miocene through lower Pliocene sections at both sites. However, these cycles disappeared in the Caribbean record about 3.8 Ma. This contrasts to the Pacific section which has cycles with these periods throughout the record. Scycles from the upper Miocene through lower Pliocene intervals of the Pacific and Caribbean show different ranges; the Caribbean section appears to record longer period S-cycles than does the Pacific section (Table 2).

Individual S-cycles can be correlated between sites only through the Brunhes (1B through $7 \mathrm{~B}$ ) and into the Matuyama (1M through $6 \mathrm{M}$ ), or from 0 to about 1.4 Ma. The individual S-cycles before about 1.4 Ma appear to be of different duration and character at each site (Fig. 5). C-cycles in both sections appear to have similar periodicities from 0 to $4 \mathrm{~m} . \mathrm{y}$., but they diverge in the section older than $4 \mathrm{~m}$.y. (Fig. 6). The timing of these divergences between the two records around $4 \mathrm{Ma}$ roughly coincides with the presumed emergence of the Isthmus of Panama (Kaneps, 1970; Keigwin, 1978, 1980; Webb, 1980; Marshall, 1980). However, a curious relationship is that prior to $4 \mathrm{Ma}$, the Caribbean and Pacific show very different $\mathrm{C}$-cycle periodicities but from $4 \mathrm{Ma}$ to the 
present the periodicities of C-cycles are quite similar (Fig. 6). This similarity is the opposite of the expected and remains unexplained.

The 500 to 600 k.y.-period cycle appears throughout the Site 503 record. Cycles of these periods apparently represent long time-scale oceanic fluctuations. The location of Site 503 far removed from any significant terrigenous input suggests that the carbonate record from Site 503 was influenced only by an oceanic response to global climatic change (i.e., intensification of corrosiveness of bottom waters), and therefore it can be considered an equatorial oceanic response for pelagic sediment. No correlation is apparent with the presumed initiation of glaciation in the Northern Hemisphere around 2.5 to 3 Ma (Kennett, 1978).

The Caribbean record reflects an oceanic response in the late Miocene and into early Pliocene, but at around $4 \mathrm{~m}$.y. the Caribbean record diverges from the Pacific record as the 500 k.y. period cycle disappears. This must be a result of the emergence of the Isthmus of Panama that closed off westward circulation and converted the Caribbean from a very wide seaway of a global ocean into a marginal sea. The improved preservation of carbonate and the higher average-carbonate content after the emergence strongly suggests that corrosive bottom waters were restricted from the Caribbean at this time. The factors that controlled the carbonate content after the Caribbean became a marginal sea were: (1) outpouring of terrigenous debris by the Rio Magdalena, (2) fluctuations of sea level that periodically stored sediment on the narrow shelves and coastal plains (interglacial conditions) and remobilized sediment via slumps, etc. (glacial conditions), and (3) deposition of volcanogenic material derived from Central and South America. All of these factors except 3 are direct responses to global climatic changes. Importantly, again no apparent changes occurred around 2.5 to $3 \mathrm{Ma}$, the inferred timing for the initiation of glaciation in the Northern Hemisphere.

\section{Possible Causes of Fluctuations of Organic Carbon: A Dilemma}

The significance of organic carbon in pelagic sediment has only recently received attention (Bordovskiy, 1965a, 1965b, 1965c; Heath et al., 1977; Muller and Suess, 1979). The strongest correlation found in these studies is a positive correlation between organic carbon and accumulation rate. Concentrations of organic carbon have been found to be at least an order of magnitude higher in hemipelagic sediment from continental margins than in pelagic sediment (Muller and Suess, 1979). This implies a significant influx of terrigenous organic matter. Organic matter in pelagic sediment is generally considered to be controlled by biologic productivity. Muller and Suess (1979) estimate that less than $0.01 \%$ of the organic carbon fixed in the surface and near-surface waters is preserved in pelagic sediment. However, they contend that fluctuations of organic carbon in pelagic sediment greater than a factor of 2 can be directly interpreted in terms of variations in paleoproductivity. Data presented by Heath et al. (1977) can also be interpreted to some extent to show a correlation with productivity, but they stress postdepositional alteration as a significant factor. Interpreting organic carbon concentrations in terms of productivity seems questionable when one considers the gross carbon cycle in the ocean. Organic carbon produced from surface and near-surface biota is recycled many times in the photic zone. The organic carbon that does reach the bottom, probably within fecal pellets, is rapidly consumed by both epiand infauna

A moving correlation coefficient (Anderson et al., 1972; Dean and Anderson, 1974, 1975) calculated for organic carbon versus carbonate from Site 502 shows there is almost no correlation between the two parameters (Fig. 12). The organic-carbon data were recalculated on a carbonate-free basis but a similar pattern emerged. The lithofacies at Site 502 is hemipelagic, but the site is removed from a continental margin and has been above the depth of an intervening basin for most of the time represented by the record. Organic carbon concentrations are within the range of those for pelagic, not hemipelagic, sediment. Consequently, a significant contribution of organic-carbon-rich sediment from the continental margins and Rio Magdalena have not reached Site 502. The general conclusion from data from Site 502 is that the paleoproductivity model is not valid for this area.

A moving correlation coefficient of carbonate versus organic carbon content from Site 503 shows a strong negative correlation, even at the $99 \%$ confidence level (Fig. 13). The lithofacies at Site 503 is pelagic throughout the section and yet high concentrations of organic carbon correlate with low carbonate content. Increased productivity in the eastern equatorial Pacific would increase carbonate accumulation, but it seems unreasonable to assign high organic-carbon values only to the siliceous biota. Data from both Sites 502 and 503 do not show the trend of reduced organic carbon with depth of burial found by Heath et al. (1977) and attributed by them to post-depositional alteration by diagenesis. The data presented by Heath et al. (1977) for the relationship between carbonate and organic carbon come from a Quaternary section south of the Aleutian Islands $\left(47^{\circ} 57^{\prime} \mathrm{N} 168^{\circ} 47^{\prime} \mathrm{E}\right)$ and a Miocene section at $10^{\circ} 03^{\prime} \mathrm{S}$ $102^{\circ} 51^{\prime} \mathrm{W}$. Both of these sections show a high positive covariance between the two parameters. These examples differ from Sites 502 and 503 both in latitude and age and these differences may explain the incompatibility.

Positive correlations have been found between organic carbon and fine-grain sizes (Bader, 1962; Gardner et al., 1979). Carbonate concentrations invariably have a positive correlation with the fine fraction. Consequently, the organic carbon record from Site $503 \mathrm{might}$ simply be a reflection of the accumulation of dissolution residue (the fine-grain size carbonate lows) and the lessdissolved pelagic sediment.

\section{CONCLUSIONS}

Late Neogene and Quaternary carbonate stratigraphies for the Caribbean and eastern equatorial Pacific show cyclic accumulations of sediment from the late Miocene through Holocene. These cycles can be best ex- 


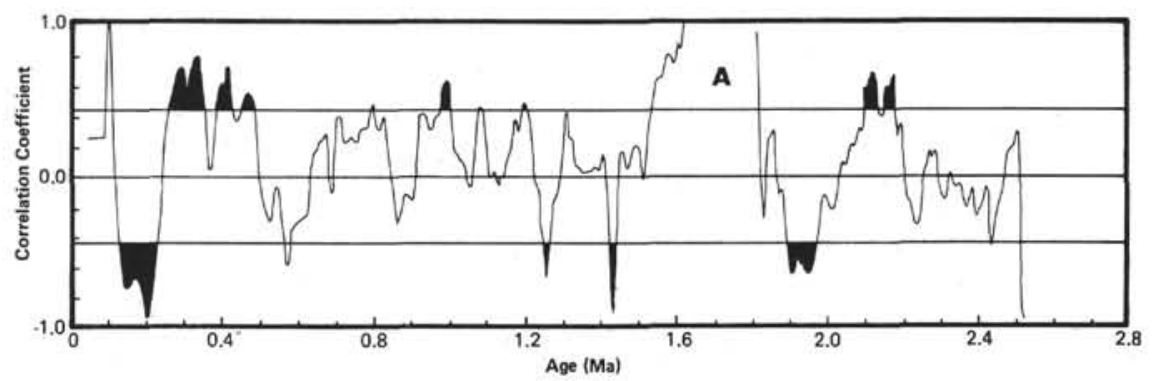

Figure 12. Moving correlation coefficient between organic carbon and carbonate for Site 502 . (The $95 \%$ level of significance is 0.433 . A 21-point window, approximately 105 k.y., was used. $\mathbf{A}=$ an artifact because of no data.)

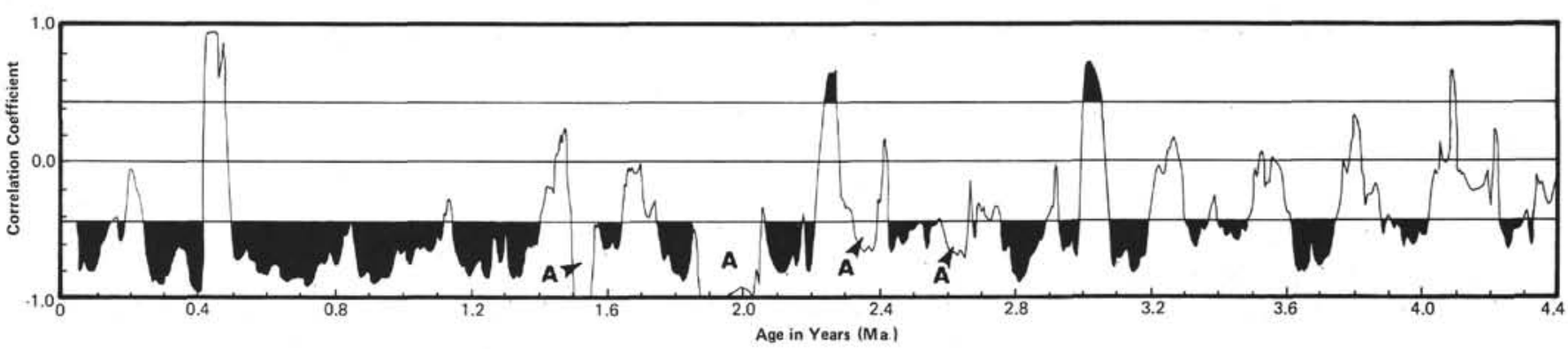

Figure 13. Moving correlation coefficient between organic carbon and carbonate for Site 503 . (The $95 \%$ level of significance is 0.433 . A 21-point window, approximately $105 \mathrm{k} . \mathrm{y}$., was used. $\mathrm{A}=\mathrm{an}$ artifact because of no data.)

plained by responses to cyclic fluctuations of global climatic conditions. The carbonate cycles from these two areas were somewhat similar until about $4.0 \mathrm{Ma}$. After that time, the two areas responded differently: Site 503 continued to act as an equatorial Pacific oceanic record, but terrigenous influences modified the record at Site 502.

The emergence of the Isthmus of Panama must have begun to block westward-flowing circulation and begun to create a marginal sea from what was a broad seaway about 4.0 Ma. This tectonic event is interpreted from the degree of carbonate preservation at Site 502 and the divergence of periodicities of carbonate cycles between Sites 502 and 503. However, no large carbonate event occurs in either record during the period of the subaerial emergence of the isthmus at about 3.5 Ma. There is a large decrease in carbonate content (from $70 \%$ to $10 \%$ ) at about $3.7 \mathrm{Ma}$ in the Site 503 record, but other large decreases of similar magnitude occur throughout the section. No correlation can be made between the presumed initiation of Northern Hemisphere glaciation and the carbonate records.

Organic carbon has almost no correlation with carbonate at Site 502, a locality where one might expect significant negative correlations. Organic carbon has a negative correlation with carbonate at Site 503, a place where one would predict strong positive correlations. The significance of the organic carbon record in marine sediment is still an unknown.

A study such as this requires an enormous amount of time to produce the raw data. The manuscript deadline imposed by DSDP was the major constraint on any rigorous analysis of the data. Thus, this paper represents preliminary work, which will be followed later by an extensive analysis of the data by time-series analysis techniques and correlations with oxygen and carbon isotope stratigraphies. The organic carbon stratigraphies, its relation to carbonate, and its significance in the sediment record, are presently being investigated.

\section{ACKNOWLEDGMENTS}

I would like to express my gratitude to DSDP/IPOD for their invitation to participate on Leg 68 of Glomar Challenger. James Barry labored at the LECO to produce the data sets and to insure its quality. To him I offer my appreciation. Walter E. Dean and Richard Z. Poore kindly reviewed the manuscript and offered invaluable advice. I thank them and absolve them from any responsibility for the conclusions.

\section{REFERENCES}

Anderson, R. Y., 1964. Varve calibration of stratification. In Merriam, D. F. (Ed.), Symposium on Cyclic Sedimentation: State Geol. Survey, Kansas Bull., 169:1-20.

Anderson, R. Y., Dean, W. E., Kirkland, D. W., and Snider, H. I., 1972. Permian Castile varved evaporite sequence, West Texas and New Mexico. Geol. Soc. Am. Bull., 83:59-86.

Arrhenius, G., 1952. Sediment cores from the East Pacific: Rep. Swed. Deep-Sea Exped. (1947-1948), 5(fusc 1):89. 1963. Pelagic sediments. In Hill, M. N. (Ed.), The Sea (Vol. 3): New York (Interscience), 655-727.

Bader, R. G., 1962. Some experimental studies with organic compounds and minerals. Univ. Rhode Island Grad. School Oceanog. Occ. Publ., 1:1-85.

Berger, A., 1977. Support for the astronomical theory of climate change. Nature, 269:44-45.

1979. Spectrum of climatic variations and their causal mechanisms. Geophys. Surveys, 3:351-402.

Berger, W. H., 1968. Planktonic foraminifera: Selective solution and paleoclimatic interpretation. Deep-Sea Res., 15:31-43.

, 1973. Deep-sea carbonates: Pleistocene dissolution cycles. J. Foram. Res., 3:187-195.

Bordovskiy, O. K., 1965a. Sources of organic matter in marine basins. Marine Geology, 3:5-32. 
1965b. Accumulation of organic matter in bottom sediments. Marine Geology, 3:33-82.

, 1965c. Transformation of organic matter in bottom sediments and its early diagenesis. Marine Geology, 3:83-114.

Briskin, M., and Harrell, J., 1980. Time-series analysis of the Pleistocene deep-sea paleoclimatic record. Marine Geology, 36:1-22.

Broecker, W. S., 1971. Calcite accumulation rates and glacial to interglacial changes in oceanic mixing. In Turekian, K. K. (Ed.), The Late Cenozoic Glacial Ages: New Haven (Yale University Press), pp. 239-265.

1974. Chemical Oceanography: New York (Harcourt Brace Jovanovich, Inc.).

Broecker, W. S., and Van Donk, J., 1970. Insolation changes, ice volumes and the $\mathrm{O}^{18}$ record in deep-sea cores. Rev. Geophys. Space Phys., 8:169-198.

Chamley, H., Diester-Haass, L., and Lange, H., 1977. Terrigenous material in east Atlantic sediment cores as an indicator of NW African climates. "Meteor" Forsch. -Ergebnisse, Reihe C, 44-59. (English)

Chase, T. E., Menard, H. W., and Mammerickx, J., 1970. Bathymetry of the North Pacific. Scripps Inst. Ocean., IMR Tech. Rept., 15.

Dean, W. E., and Anderson, R. Y., 1974. Application of some correlation coefficient techniques to time-series analysis. Math. Geol., 6:363-372.

, 1975. Trace and minor element variations in the Permian Castile Formation, Delaware Basin, Texas and New Mexico, revealed by varve calibration. Fourth Symposium on Salt (Vol. 1): Cleveland (Northern Ohio Geol. Soc.), 275-285.

Dean, W. E., Gardner, J. V., Jansa, L. F., Ċepek, P., and Seibold, E., 1977. Cyclic sedimentation along the continental margin of northwest Africa. In Lancelot, Y., Seibold, E., et al., Init. Repts. DSDP, 41: Washington (U.S. Govt. Printing Office), 965-989.

Dean, W. E., Gardner, J. V., and Čepek, P., 1981. Tertiary carbonatedissolution cycles on the Sierra Leone Rise, eastern equatorial Atlantic Ocean. Marine Geology, 39:81-101.

Diester-Haass, L., 1976. Late Quaternary climatic variations in NW Africa deduced from east Atlantic sediment cores. Quat. Res., 6 : 299-314.

Donnelly, T. W., 1975. The geological evolution of the Caribbean and Gulf of Mexico-some critical problems and areas. In Nairn, A. E. M., and Stehli, F. G. (Eds.), The Ocean Basins and Margins, The Gulf of Mexico and the Caribbean (Vol. 3): New York (Plenum Press), 663-689.

Dunn, D. A., Moore, T. C., Jr., Keigwin, L. D., Jr., and Woodruff, F., 1980. An apparent "Atlantic-type" carbonate stratigraphy in the late Miocene equatorial Pacific Ocean. Geol. Soc. Am. Abst., 12:417. (Abstract)

Edgar, N. T., Saunders, J. B., et al., 1973. Init. Repts. DSDP, 15: Washington (U.S. Govt. Printing Office).

Emiliani, C., 1978. The cause of the Ice Ages. Earth Planet. Sci. Lett., $37: 349-352$

Fox, P. J., Schreiber, E., and Heezen, B. C., 1971. The geology of the Caribbean crust: Tertiary sediments, granitic and basic rocks from the Aves Ridge. Tectonophysics, 12:89-109.

Gardner, J. V., 1975. Late Pleistocene carbonate dissolution cycles in the eastern equatorial Atlantic. In Sliter, W. V., Bé, A. W.H., and Berger, W. H. (Eds.), Dissolution of Deep-Sea Carbonates, Spec. Publ. Cushman Found. Foraminiferal Res., 13:129-141.

Gardner, J. V., Dean, W. E., and Vallier, T. L., 1979. Sedimentology and geochemistry of surface sediments, outer continental shelf, southern Bering Sea. Marine Geology, 35:299-329.

Gardner, J. V., and Hays, J. D., 1976. Responses of sea-surface temperature and circulation to global climatic change during the past 200,000 years in the eastern equatorial Atlantic Ocean. In Cline, R. M., and Hays, J. D. (Eds.), Investigation of late Quaternary Paleoceanography and Paleoclimatology, Mem. Geol. Soc. Am., $145: 221-246$.

Hays, J. D., Imbrie, J., and Shackleton, N. J., 1976. Variations in the earth's orbit: Pacemaker of the Ice Ages. Science, 194:1121-1132.

Hays, J. D., Saito, T., Opdyke, N. D., and Burckle, L. H., 1969. Pliocene-Pleistocene sediments of the equatorial Pacific: Their paleomagnetic, biostratigraphic, and climatic record. Geol. Soc. Am. Bull., 80:1481-1514.
Heath, G. R., Moore, T. C., Jr., and Dauphin, J. P., 1977. Organic carbon in deep-sea sediments. In Anderson, N. R., and Malahoff, A. (Eds.), The Fate of Fossil Fuel $\mathrm{CO}_{2}$ in the Oceans: New York (Plenum Press), pp. 605-625.

Hey, R., 1977. Tectonic evolution of the Cocos-Nazca spreading center. Geol. Soc. Am. Bull., 88:1404-1420.

Holcombe, T. L., 1975. Caribbean bathymetry and sediments. Geology, Geophysics, and Resources of the Caribbean. Rept. of IDOE workshop on geology and marine geophysics of the Caribbean region and its resources, Kingston, Jamaica, pp. 27-62.

Kaneps, A. G., 1970. Late Neogene biostratigraphy (planktonic foraminifera), biogeography, and depositional history [Ph.D. dissert.]. Columbia University, New York.

1973. Carbonate chronology for Pliocene deep-sea sediments. In van Andel, Tj. H., Heath, G. R., et al., Init. Repts. DSDP, 16: Washington (U.S. Govt. Printing Office), 873-881.

Keigwin, L. D., Jr., 1978. Pliocene closing of the Isthmus of Panama, based on biostratigraphic evidence from nearby Pacific Ocean and Caribbean Sea cores. Geology, 6:630-634.

1980. Deep Sea Drilling Project (DSDP) evidence for the closing of the Central American Seaway. Geol. Soc. Am., Abst. Prog., 12:459.

Kennett, J. P., 1978. The development of planktonic biogeography in the Southern Ocean during the Cenozoic. Marine Micropaleo., 3: 301-345.

Kominz, M. A., and Pisias, N. G., 1979. Pleistocene climate: deterministic or stochastic? Science, 204:171-172.

LaBrecque, J. L., Kent, D. V., and Cande, S. C., 1977. Revised magnetic polarity time scale for Late Cretaceous and Cenozoic time. Geology, 5:330-335.

Luz, B., and Shackleton, N. J., 1975. $\mathrm{CaCO}_{3}$ solution in the tropical east Pacific during the past 130,000 years. In Sliter, W. V., Bé, A.W.H., and Berger, W. H. (Eds.), Dissolution of Deep-Sea Carbonates. Spec. Publ. Cushman Found. Foraminiferal Res., 13: $142-150$.

Mammerickx, J., Smith, S. M., Taylor, I. L., and Chase, T. E., 1974. Bathymetry of the South Pacific. Scripps Inst. Ocean., IMR Tech. Rept., 48A.

Marshall, L. G., 1980. South American mammalian chronology and the interamerican interchange. Geol. Soc. Am. Abst. Prog., 12: 476.

Mesolella, K. J., Matthews, R. K., Broecker, W. S., and Thurber, D. L., 1969. The astronomical theory of climatic change: Barbados data. J. Geology, 77:250-274.

Milankovitch, M., 1930. Mathematische klimalehre und Astronomische Theorie der kimaschwankungen. In Koppen, W., and Geiger, R. (Eds.), Handb. Klimatologie, 1(A):1-176.

Moore, T. C., Jr., Pisias, N. G., and Heath, G. R., 1977. Climate changes and lags in Pacific carbonate preservation, sea surface temperature and global ice volume. In Anderson, N. R., and Malahoff, A. (Eds.), The Fate of Fossil Fuel $\mathrm{CO}_{2}$ in the Oceans: New York (Plenum Press), 145-165.

Müller, G., and Gastner, M., 1971. The "Karbonat Bombe," a simple device for the determination of carbonate content in sediments, soils, and other materials. N. Jb. Mineral. Mh., 10:466-469.

Muller, P. J., and Suess, E., 1979. Productivity, sedimentation rate; and sedimentary organic matter in the oceans-I. Organic carbon preservation. Deep Sea Res., 26A:1347-1362.

Newell, R. E., 1973. Climate and the Galapagos Islands. Nature, 245: 91-92.

Ninkovich, D., and Shackleton, N. J., 1975. Distribution, stratigraphic position and age of ash Layer "L," in the Panama Basin region. Earth Planet. Sci. Lett., 27:20-34.

Olausson, E., 1965. Evidence of climatic changes in North Atlantic deep-sea cores with remarks on isotopic paleotemperature analysis. In Sears, M. (Ed.), Progress in Oceanography: London (Pergamon Press), 3:221-252.

1967. Climatological, geoeconomical, and paleo-oceanographical aspects of carbonate deposition. In Sears, M. (Ed.), Progress in Oceanography: London (Pergamon Press), 4:245-265.

Pisias, N. G., Heath, G. R., and Moore, T. C., Jr., 1975. Lag times for oceanic responses to climatic change. Nature, 256:716-717.

Prell, W. L., 1978. Upper Quaternary sediments of the Colombia Basin: Spatial and stratigraphic variations. Geol. Soc. Am. Bull., 89: 1241-1255. 
Ramsay, A. T. S., 1977. Sedimentological clues to paleo-oceanography. In Ramsay, A. T. S. (Ed.), Oceanic Micropaleontology: New York (Academic Press), 2:1371-1453.

Shackleton, N. J., and Opdyke, N. D., 1976. Oxygen-isotope and paleomagnetic stratigraphy of Pacific Core V28-239 late Pliocene to latest Pleistocene. In Cline, R. M., and Hays, J. D. (Eds.), Investigation of Late Quaternary Paleoceanography and paleoclimatology: Mem. Geol. Soc. Am., 145:449-464.

Thompson, P. R., and Saito, T., 1974. Pacific Pleistocene sediments: Planktonic Foraminifera dissolution cycles and geochronology. Geology, 2:333-335.

Thompson, P. R., and Sciarrillo, J. R., 1978. Planktonic foraminiferal biostratigraphy in the equatorial Pacific. Nature, 275:29-33.

Tomblin, J. F., 1975. The Lesser Antilles and Aves Ridge. In Nairn, A. E. M., and Stelhi, F. G. (Eds.). The Ocean Basins and Margins, The Gulf of Mexico and the Caribbean (Vol. 3): New York (Plenum Press), 467-500.

Vallencia, M. J., 1977. Pacific Pleistocene paleoclimatic stratigraphies: A comparative analysis of results. Quat. Res., 8:339-354.

van Andel, Tj. H., Heath, G. R., and Moore, T. C., Jr., 1975. Cenozoic history and paleoceanography of the central equatorial $\mathrm{Pa}$ cific Ocean. Mem. Geol. Soc. Am., 143.

Webb, S. D., 1980. North American mammalian chronology and the interamerican interchange. Geol. Soc. Am. Abst. Prog., 12:546.

Wiseman, J. D. H., 1975. The changing rate of calcium carbonate sedimentation on the equatorial Atlantic floor and its relation to continental Late Quaternary stratigraphy. Rep. Swed. Deep-Sea Exped. (1947-1948), 7:289-354.
APPENDIX B

Composite Sections

Schemes used to construct composite sections versus depth for Sites 502 and 503.

\begin{tabular}{|c|c|}
\hline Hole & $\begin{array}{c}\text { Interval } \\
\text { (m) }\end{array}$ \\
\hline \multicolumn{2}{|l|}{ Site 502} \\
\hline $\begin{array}{l}502 \mathrm{~A} \\
502 \mathrm{~B} \\
502 \\
502 \mathrm{~B} \\
502 \mathrm{C} \\
502 \mathrm{~B} \\
502 \\
502 \mathrm{~A} \\
502 \\
502 \mathrm{~B} \\
502 \\
502 \mathrm{~B} \\
502 \\
502 \mathrm{~A} \\
502 \\
502 \mathrm{~A}\end{array}$ & $\begin{array}{c}0-3.83 \\
3.84-37.08 \\
37.30-42.09 \\
42.74-45.60 \\
46.97-51.71 \\
51.86-61.55 \\
62.33-64.71 \\
65.50-66.41 \\
67.00-69.10 \\
69.15-79.15 \\
79.96-86.78 \\
86.94-88.44 \\
88.90-96.71 \\
97.00-122.58 \\
122.65-125.29 \\
125.70-212.10\end{array}$ \\
\hline \multicolumn{2}{|l|}{ Site 503} \\
\hline $\begin{array}{l}503 \mathrm{~B} \\
503 \mathrm{~A} \\
503 \mathrm{~B} \\
503 \mathrm{~A} \\
503 \mathrm{~B} \\
503 \mathrm{~A} \\
503 \mathrm{~B} \\
503 \mathrm{~A} \\
503 \mathrm{~B} \\
503 \mathrm{~A} \\
503 \mathrm{~B} \\
503 \mathrm{~A} \\
503 \mathrm{~B} \\
503 \mathrm{~A}\end{array}$ & $\begin{array}{r}0-24.51 \\
25.30-27.46 \\
27.94-33.94 \\
34.02-39.62 \\
39.97-40.87 \\
41.13-42.82 \\
43.00-54.70 \\
54.80-55.10 \\
55.85-84.66 \\
84.74-86.40 \\
86.55-101.45 \\
101.52-103.63 \\
104.31-110.58 \\
120.80-234.62\end{array}$ \\
\hline
\end{tabular}

